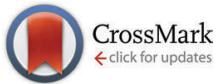

Cite this: New J. Chem., 2015 39, 7194

Received (in Montpellier, France) 12th March 2015 ,

Accepted 8th July 2015

DOI: 10.1039/c5nj00620a

www.rsc.org/njc

\section{Synthesis and characterization of bifunctional dendrimers: preliminary use for the coating of gold surfaces and the proliferation of human osteoblasts (HOB) $\dagger$}

\author{
Edwin R. de Jong, ${ }^{\mathrm{abc}}$ Nicole Deloch, ${ }^{c}$ Wolfgang Knoll, ${ }^{c d}$ Cédric-Olivier Turrin, ${ }^{\mathrm{ab}}$ \\ Jean-Pierre Majoral, ${ }^{\text {ab }}$ Anne-Marie Caminade ${ }^{\star a b}$ and Ingo Köper ${ }^{c e}$
}

\begin{abstract}
Two different novel families of bifunctional water-soluble dendrimers are synthesized, using the specific functionalization of one function of the cyclotriphosphazene core. Dendrimers are grown from the 5 remaining functions, up to generation 2 . Water-solubility is attained in the last step of the synthesis by grafting either ammonium terminal groups or carboxylate terminal groups, on generations 1 and 2 of these bifunctional dendrimers. 12 new compounds are synthesized and fully characterized, in particular by multi-nuclear NMR. The function linked to the core is thioctic acid, suitable for grafting onto gold, thus both types of water-soluble dendrimers can be used to coat gold surfaces. These macromolecular assemblies are characterized by surface plasmon resonance (SPR). In a preliminary attempt, the gold surfaces modified by either positively or negatively charged dendrimers are used for studying their interaction with cells. Exposed to human osteoblast cells (OBC), the influence of the surface coatings on the cell responses is investigated. Polycationic dendrimers provoke cell apoptosis, whereas negatively charged dendrimers support cell adhesion and proliferation.
\end{abstract}

\section{Introduction}

Dendrimers $^{1}$ are macromolecules with a regularly branched and repetitive structure that are synthesized in an iterative fashion. Due to their monodispersity, well-defined shape and extremely high functionality, dendrimers are ideal nano-sized objects for functional and biocompatible surface coatings. Furthermore, dendrimers play an important role as versatile tools in nano-medicine. ${ }^{2}$ In most cases dendrimers have numerous but identical terminal groups. However, the demand on their structural complexity is increasing, ${ }^{3}$ and there is a real need for elaborating strategies toward bifunctional dendrimers. Such an approach is particularly suitable for the functionalization of the surface of materials at the nanometric scale. ${ }^{4}$

\footnotetext{
${ }^{a}$ CNRS, LCC (Laboratoire de Chimie de Coordination), 205 Route de Narbonne, BP 44099, F-31077 Toulouse Cedex 4, France.

E-mail: anne-marie.caminade@lcc-toulouse.fr

${ }^{b}$ Université de Toulouse, UPS, INPT, F-31077 Toulouse Cedex 4, France

${ }^{c}$ Max-Planck Institute for Polymer Research, Ackermannweg 10, 55128 Mainz, Germany

${ }^{d}$ Austrian Institute of Technology, Donau-City-Straße 1, 1220 Vienna, Austria ${ }^{e}$ Flinders Centre for NanoScale Science and Technology, School of Chemical and Physical Sciences, Flinders University, Sturt Road, Adelaide SA 5001, Australia. E-mail: ingo.koeper@flinders.edu.au

$\dagger$ Electronic supplementary information (ESI) available: NMR spectra of all compounds and contact angle goniometry data. See DOI: 10.1039/c5nj00620a
}

Extensive studies on cell-surface interactions have indicated that surface properties such as hydrophilicity, ${ }^{5}$ surface charge, surface energy, ${ }^{6}$ protein adsorption ${ }^{7}$ and surface topography and morphology ${ }^{8}$ have a significant effect on these interactions. Typically, cationic charges enhance cell attachment, possibly through electrostatic attraction, ${ }^{9}$ as it was shown for instance for human umbilical vein endothelial cells, ${ }^{10}$ and several other types of cells. ${ }^{11}$ In addition, different cell types typically react entirely differently to an environment; ${ }^{12}$ therefore a detailed study on every surface coating is necessary. So far, dendrimers have been used only occasionally for cell-attractive surface coatings, despite the fact that their multivalency should enhance the binding avidity towards cells. Rat neurons showed a high affinity and proliferation rate on multilayered generation $4\left(\mathrm{G}_{4}\right)$ poly(phosphorhydrazone) dendrimer surfaces that were created by a layer-by-layer deposition technique, with the neurons showing a preference for positively charged outer layers. ${ }^{13}$ Human corneal epithelial cells and mouse fibroblasts showed good adhesion on $\left(\mathrm{G}_{1}-\mathrm{G}_{4}\right)$ dendronized surfaces with hydroxyl extremities (non-ionic) of the polyamidoamine-based (PAMAMbased) cascade structure. ${ }^{14}$ Human fibroblasts and myoblasts also adhered on surfaces coated with D-glucose terminated dendrimers, ${ }^{15}$ and embryonic stem cells were maintained in an undifferentiated state on the same surface. ${ }^{16}$ Recently, surfaces coated with PAMAM generation 7 dendrimers modified with anti-epithelial 
cell adhesion molecules (one of the most commonly used circulating tumour cells capturing agents) were efficiently used for the capture of circulating tumour cells in peripheral blood. ${ }^{17}$

The surface attachment of osteoblast cells is of particular interest for many biomedical applications. These cells interact with the surface of bones, as they are continuously involved in renewing and reshaping bone tissue. They are also important when a foreign material needs to be inserted into the body, for example in the case of implants. It was found that positively charged amino-coated titanium surfaces enhanced the first steps towards osteoblast adhesion, compared to negatively charged surfaces. ${ }^{18}$ This could be related to the negative charge of hyaluronan that is involved in the early adhesion process. ${ }^{19}$ TiOx surfaces modified with biotinylated fibronectin (a partial aminoacid sequence of an extracellular matrix protein) adsorbed on a streptavidin-silane self-assembled multilayer were also found effective for osteoblast adhesion. ${ }^{20}$ However, to our knowledge, no experiment to date involving osteoblasts has been carried out with dendrimer coated surfaces.

Here we report the synthesis of two new series of bifunctional dendrimers based on a phosphorus scaffold of the type poly(phosphorhydrazone), a well-established bio-compatible element. ${ }^{21}$ Gold surfaces are chosen to be coated by the dendrimers, as any modification on this surface can be easily investigated by surface plasmon resonance (SPR) spectroscopy and other surface analytical techniques. ${ }^{22}$ For this purpose, the dendrimers are functionalized with one dithiolane group linked to the core, suitable for the formation of self-assembled monolayers on gold surfaces, due to the well-known affinity of gold to thiols. Positively or negatively charged functions are used as terminal groups, to confer a hydrophilic character to the surface of the dendrimer, ${ }^{23}$ and thus to the coated surface. As it has been already shown that the nature of the charges (positive or negative) strongly influences the behaviour of the cells, the presence of charges as terminal groups of dendrimers will enable a comparison with these data. ${ }^{18}$ The formation of a self-assembled monolayer on a gold substrate is characterized by surface plasmon resonance (SPR) spectroscopy. In a preliminary attempt, the coated surfaces are exposed to human osteoblast (HOB) cells and their adhesion and proliferation are studied by optical microscopy and biochemical assays.

\section{Results and discussion}

\section{Synthesis and characterization of bifunctional dendrimers}

Hexachlorocyclotriphosphazene is an interesting core for dendrimers, as it possesses 6 functions for growing the branches, instead of 3 or 4 for most classical cores. Furthermore, we have previously shown that it is possible to differentiate one function among six, affording $\mathrm{AB}_{5}$-type compounds, suitable to elaborate non symmetrical dendrimers ${ }^{24}$ or highly dense dendrimers. ${ }^{25}$ The possibility of differentiating the reactivity of each $\mathrm{Cl}$ in $\mathrm{P}(\mathrm{X}) \mathrm{Cl}_{2}$ groups $(\mathrm{X}=\mathrm{S}, \mathrm{O} \text {, or } \mathrm{NR})^{26}$ is particularly relevant for the design of new bifunctional dendrimers. The A function is the dithiolane group for grafting onto the gold surface, and the $\mathrm{B}$ functions are aldehydes, which are suitable starting points for the synthesis of the branches of poly(phosphorhydrazone) dendrimers, ${ }^{27}$ and further functionalizations. The reaction of phenols with $\mathrm{P}-\mathrm{Cl}$ functions is the most convenient reaction (easy and quantitative) for the functionalization of phosphorus dendrimers under basic conditions. Thus we used hydroxybenzaldehyde as the B group and we grafted tyramine to thioctic acid by peptide coupling to elaborate the A group, which contains a phenol also (compound 1, Scheme 1).

In order to obtain the $\mathrm{AB}_{5}$ core, two strategies can be envisaged: either by first grafting one dithiolane derivative 1 onto the core followed by the reaction of 5 equivalents of hydroxybenzaldehyde (Way a, Scheme 1) or grafting first 5 equivalents of hydroxybenzaldehyde then the dithiolane derivative $\mathbf{1}$ (Way b, Scheme 1). We tested both the strategies. Way a yielded the expected compound 2 as the major product, characterized by the presence of one doublet at $22.4 \mathrm{ppm}$ in the ${ }^{31} \mathrm{P}$ NMR spectrum, and a pseudo triplet at $12.2 \mathrm{ppm}\left({ }^{2} J_{\mathrm{PP}}=64 \mathrm{~Hz}\right)$, characteristic of a single substitution on $\mathrm{N}_{3} \mathrm{P}_{3} \mathrm{Cl}_{6}$. However, the ${ }^{31} \mathrm{P}$ NMR spectrum displays also the presence of small impurities (about 5\%) that
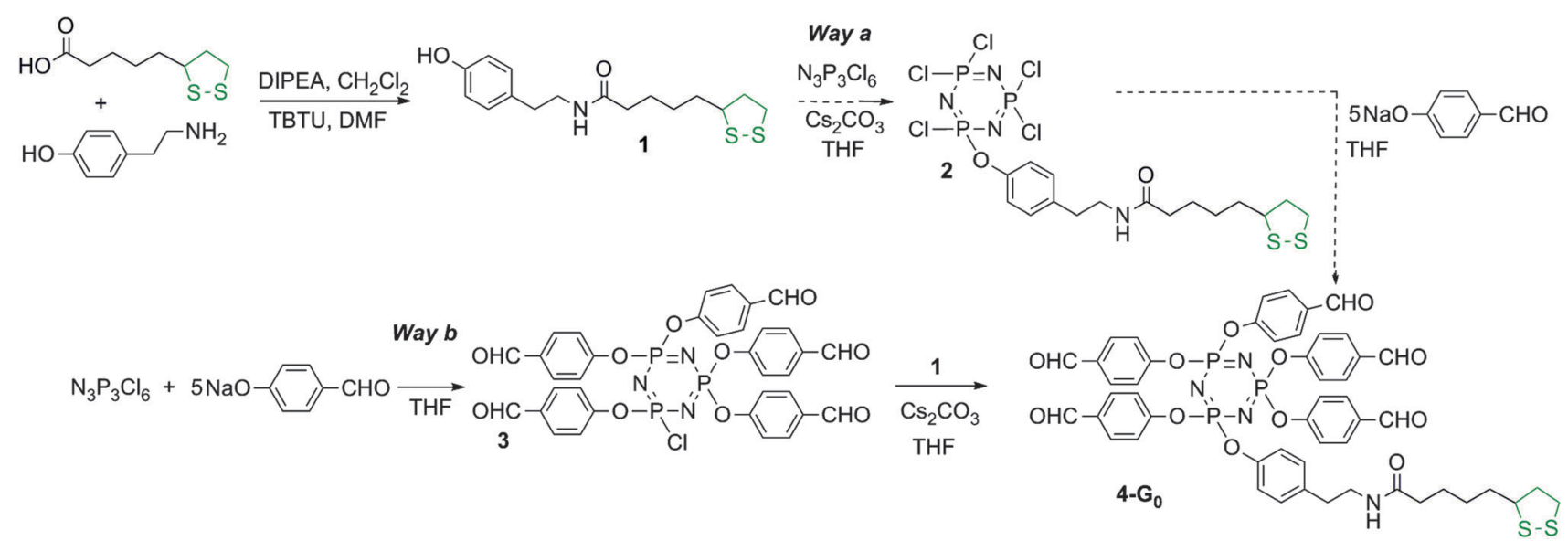

Scheme 1 Synthesis of the dithiolane derivative $\mathbf{1}$, and two strategies for its grafting to the cyclotriphosphazene core. Only Way $\mathbf{b}$ affords pure compounds. 
could not be removed in the purification process. Way b yielded cleanly the pentaaldehyde $3,^{28}$ characterized by the presence of a pseudo triplet at $20.8 \mathrm{ppm}$ and a doublet at $5.1 \mathrm{ppm}\left({ }^{2} J_{\mathrm{PP}}=\right.$ $84 \mathrm{~Hz}$ ) in the ${ }^{31} \mathrm{P}$ NMR spectrum. The grafting of compound 1 in the second step induces the disappearance of these signals and the appearance of a pseudo singlet at $7.4 \mathrm{ppm}$ for compound $\mathbf{4}-\mathbf{G}_{\mathbf{0}}$. We also tried to obtain compound $\mathbf{4}-\mathbf{G}_{\mathbf{0}}$ by continuing the process of Way a, i.e. by reacting 5 equivalents of hydroxybenzaldehyde with compound 2 . The reaction worked, but some impurities from the previous step could not be removed. Thus, only compound $\mathbf{4}-\mathbf{G}_{\mathbf{0}}$ obtained through Way $\mathbf{b}$ was used in the subsequent steps (Scheme 1).

The condensation of 5 equivalents of $\mathrm{H}_{2} \mathrm{NNMeP}(\mathrm{S}) \mathrm{Cl}_{2}$ resulted in the first generation bifunctional dendrimer $\mathbf{5}-\mathbf{G}_{\mathbf{1}}$. The completion of the reaction is shown by the disappearance of the signals corresponding to the aldehydes both in ${ }^{1} \mathrm{H}$ and ${ }^{13} \mathrm{C}$ NMR. Compound $\mathbf{5}-\mathbf{G}_{\mathbf{1}}$ is the starting material for pursuing the growth of the branches. Compound $\mathbf{5}-\mathbf{G}_{\mathbf{1}}$ is reacted with 10 equivalents of hydroxybenzaldehyde. The completion of the reaction affording $\mathbf{4}-\mathbf{G}_{\mathbf{1}}$ is detected by ${ }^{31} \mathrm{P}$ NMR, which displays the disappearance of the intermediate singlet at $69 \mathrm{ppm}$, corresponding to the monosubstitution $\left(\mathrm{P}(\mathrm{S}) \mathrm{Cl}\left(\mathrm{OC}_{6} \mathrm{H}_{4} \mathrm{CHO}\right)\right)$ on behalf of the appearance of a singlet at $60.4 \mathrm{ppm}$, corresponding to the full substitution. Starting from compound $\mathbf{4}-\mathbf{G}_{\mathbf{1}}$, the second generation of the bifunctional dendrimer is obtained by the condensation with $\mathrm{H}_{2} \mathrm{NNMeP}(\mathrm{S}) \mathrm{Cl}_{2}$. Compound $\mathbf{5}-\mathbf{G}_{\mathbf{2}}$ is isolated and characterized, as $\mathbf{5}-\mathbf{G}_{\mathbf{1}}$ previously. It is in particular characterized in ${ }^{31} \mathrm{P}$ NMR by the presence of three singlets at $8.3 \mathrm{ppm}\left(\mathrm{N}_{3} \mathrm{P}_{3}\right), 61.9 \mathrm{ppm}$ (the $5 \mathrm{P}=\mathrm{S}$ groups of the first generation), and $62.8 \mathrm{ppm}$ (the $10 \mathrm{P}=\mathrm{S}$ groups of the second generation). Compound $\mathbf{5}-\mathbf{G}_{\mathbf{2}}$ is then reacted with 4 -hydroxybenzaldehyde to afford dendrimer $\mathbf{4}-\mathbf{G}_{\mathbf{2}}$ (Scheme 2). In this case also, ${ }^{31} \mathrm{P}$ NMR displays the appearance of the intermediate singlet at $69 \mathrm{ppm}$, corresponding to the monosubstitution, which disappears when the reaction has reached completion. All these steps are compatible with the presence of the dithiolane linked to the core, as shown by ${ }^{1} \mathrm{H}$ and ${ }^{13} \mathrm{C} \mathrm{NMR}$, with unchanged signals corresponding to the $\mathrm{CH}$ and $\mathrm{CH}_{2}$ groups of the 5-membered ring.
Dendrimers $\mathbf{4}-\mathbf{G}_{\mathbf{1}}, \mathbf{4}-\mathbf{G}_{\mathbf{2}}, \mathbf{5}-\mathbf{G}_{\mathbf{1}}$, and $\mathbf{5}-\mathbf{G}_{\mathbf{2}}$ are the precursors of the hydrophilic bifunctional dendrimers suitable for grafting onto the gold surface. For this purpose, two different strategies have been applied. For obtaining positively charged dendrimers, $\mathrm{N}, \mathrm{N}$-diethylethylenediamine is reacted with the $\mathrm{P}(\mathrm{S}) \mathrm{Cl}_{2}$ terminal groups (1 diamine per $\mathrm{Cl}$ ). $\mathrm{HCl}$ generated in the reaction is trapped by the tertiary amine moieties, ${ }^{29}$ affording directly the water-soluble bifunctional dendrimer $\mathbf{6}-\mathbf{G}_{\mathbf{1}}$ from $\mathbf{5}-\mathbf{G}_{\mathbf{1}}$. As the protonation of the tertiary amine is reversible, the percentage of protonation varies depending on the media, and in particular depending on the $\mathrm{pH}^{13}$ The simultaneous presence of the two types of terminal groups is clearly detected by ${ }^{1} \mathrm{H}$ and ${ }^{13} \mathrm{C} \mathrm{NMR}$, in particular for the $\mathrm{CH}_{3}$ groups of $\mathrm{NH}^{+}\left(\mathrm{CH}_{2} \mathrm{CH}_{3}\right)_{2}$ (major, $\delta{ }^{1} \mathrm{H}=1.33 \mathrm{ppm}(\mathrm{t}), \delta{ }^{13} \mathrm{C}=7.8 \mathrm{ppm}$ ) and $\mathrm{N}\left(\mathrm{CH}_{2} \mathrm{CH}_{3}\right)_{2}$ (minor, $\delta{ }^{1} \mathrm{H}=1.26 \mathrm{ppm}(\mathrm{t}), \delta{ }^{13} \mathrm{C}=9.0 \mathrm{ppm}$ ). The same type of reaction is applied to compound $\mathbf{5}-\mathbf{G}_{\mathbf{2}}$, used as a precursor for the synthesis of the water-soluble bifunctional dendrimer 6-G $\mathbf{G}_{\mathbf{2}}$ (Scheme 3).

Compound $\mathbf{4}-\mathbf{G}_{\mathbf{1}}$ is the starting point for affording another type of water-soluble (negatively charged) bifunctional dendrimer suitable for grafting onto gold surfaces. For this purpose, a Doebner-like reaction is carried out with malonic acid in pyridine with a catalytic amount of piperidine. ${ }^{30}$ This reaction affords compound $\mathbf{7}-\mathbf{G}_{\mathbf{1}}$ ending with carboxylic acids. The characterization is performed at this step. The completion of the reaction is shown by ${ }^{1} \mathrm{H} \mathrm{NMR}$, with the disappearance of the signal corresponding to the aldehydes on behalf of two doublets at 6.43 and $7.19 \mathrm{ppm}\left({ }^{3} \mathrm{~J}_{\mathrm{HH}}=15.9 \mathrm{~Hz}\right)$, corresponding to the alkene groups. Compound $\mathbf{7}-\mathbf{G}_{\mathbf{1}}$ ending with carboxylic acids is not soluble in water, contrarily to its sodium salt, obtained by the addition of $\mathbf{N a O H}$. Finally, compound $\mathbf{4}-\mathbf{G}_{\mathbf{2}}$ is used as a precursor for dendrimer $\mathbf{7}-\mathbf{G}_{\mathbf{2}}$, obtained from the reaction with malonic acid (Scheme 4 displays the full structure of compound $\mathbf{7}-\mathbf{G}_{\mathbf{2}}$, after reaction with $\left.\mathrm{NaOH}\right) .{ }^{31} \mathrm{P} \mathrm{NMR}$ displays the presence of 3 signals corresponding to the core $\mathrm{N}_{3} \mathrm{P}_{3}(8.4 \mathrm{ppm})$ and the $\mathrm{P}=\mathrm{S}$ groups of the first $(62.4 \mathrm{ppm})$ and second (62.0 ppm) layers. Interestingly, all these steps also are compatible with the presence of the dithiolane function linked to the core. Indeed, it is by far not trivial to have at each step of

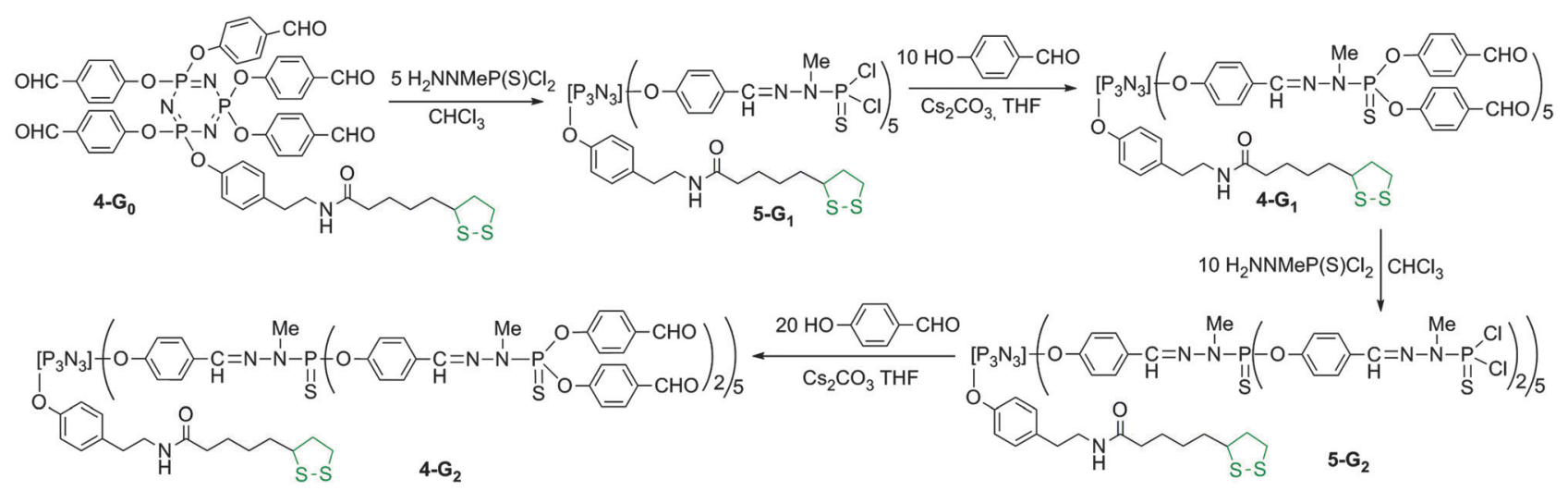

Scheme 2 Synthesis of bifunctional dendrimers having one dithiolane function at the core, and either $\mathrm{Cl}\left(\mathbf{5}-\mathbf{G}_{\mathbf{1}}\right.$ and $\left.\mathbf{5}-\mathbf{G}_{\mathbf{2}}\right)$ or $\mathrm{CHO}\left(\mathbf{4}-\mathrm{G}_{\mathbf{1}}\right.$ and $\left.\mathbf{4}-\mathrm{G}_{\mathbf{2}}\right)$ terminal functions. 

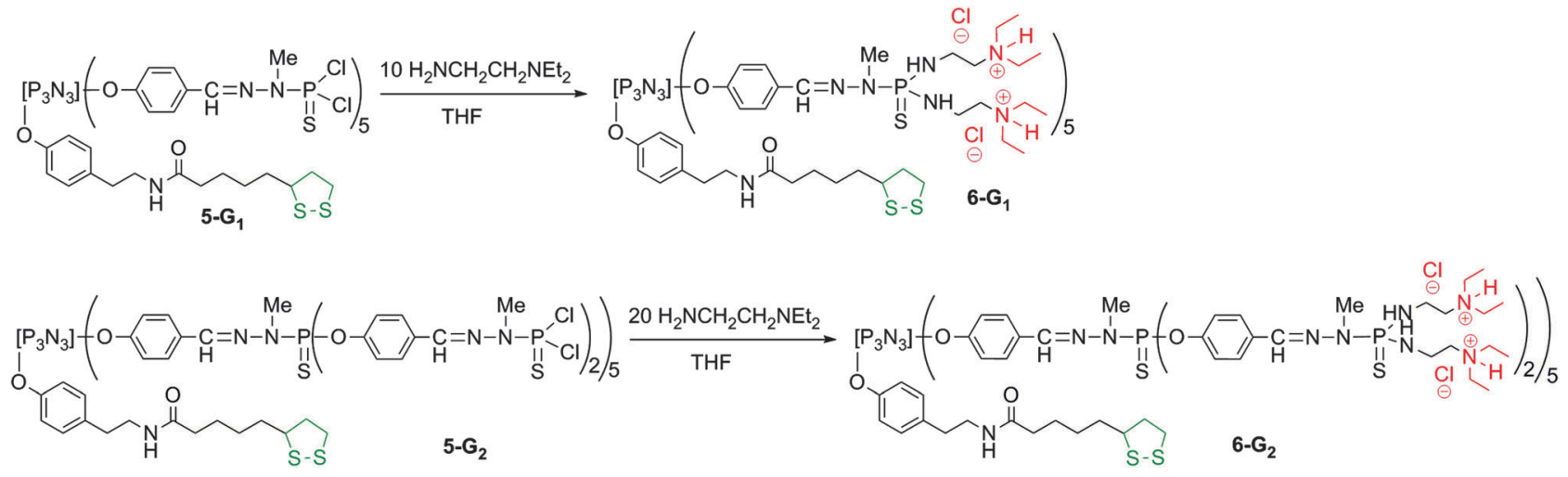

Scheme 3 Synthesis of water-soluble bifunctional dendrimers having one dithiolane function at the core, and $10\left(\mathbf{6}-\mathbf{G}_{1}\right)$ or $20\left(\mathbf{6}-\mathbf{G}_{2}\right)$ ammonium terminal groups.

the multi-step synthesis of dendrimers two types of functions that do not interfere.

\section{Gold surface coating with the bifunctional dendrimers}

Thin glass slides commonly used for optical microscopy were coated with thin layers of chromium $(5 \mathrm{~nm})$ and gold $(48 \mathrm{~nm})$. In the first attempt, dendrimers $\mathbf{6}-\mathbf{G}_{\mathbf{1}}$ and $\mathbf{7}-\mathbf{G}_{\mathbf{1}}$ were used in solution in water. A self-assembled layer of the bifunctional first generation dendrimer was formed on the gold surfaces. The dendrimers attach to the gold surface through the dithiolane moiety at the core, which strongly binds to gold via quasi-covalent bonds. ${ }^{31}$ The successful assembly process was characterized by contact angle and surface plasmon resonance (SPR) measurements. After about five hours, the binding process was completed. Fig. 1 displays the SPR angular scans of a gold sample coated with either dendrimer $\mathbf{6}-\mathbf{G}_{\mathbf{1}}$ or dendrimer $\mathbf{7}-\mathbf{G}_{\mathbf{1}}$. Assuming a refractive index of $1.5^{32}$ for the dendrimer layer, film thicknesses of about $1.0 \mathrm{~nm}$ were obtained. This low value suggests that the hydrophobic interior of the dendrimers collapses upon contact with the aqueous environment. This is in agreement with the behaviour of phosphorus dendrimers in water measured earlier. ${ }^{33}$ Analogous experiments were attempted with the second generations of the bifunctional dendrimers $\mathbf{6}-\mathbf{G}_{\mathbf{2}}$ and $\mathbf{7}-\mathbf{G}_{\mathbf{2}}$ but failed, presumably due to the protection/shielding of the dithiolane induced by the branches of the dendrimers, which prevents the interaction with the gold surface.

Water contact angle measurements (see ESI $\dagger$ ) showed contact angles of approximately $50^{\circ}$ for both the polycationic and polyanionic first generation dendrimer coatings. This value suggests that the hydrophobic interior of the dendrimers is exposed to the aqueous phase, resulting in a film without extreme polarity for both $\mathbf{6}-\mathbf{G}_{\mathbf{1}}$ and $\mathbf{7}-\mathbf{G}_{\mathbf{1}}$.

\section{Human osteoblast (HOB) cell proliferation on dendrimer functionalized surfaces}

In order to demonstrate the potential utility of the new water soluble bifunctional dendrimers in biology, the dendrimercoated glass substrates were exposed to a cell culture of human osteoblast HOB cells and the proliferation behaviour of these cells was studied optically. Optical microscopy is a valuable method for assessing cell morphology during cell adhesion and proliferation. During the first 24 hours, the cells were observed several times in order to follow the cell attachment and spreading process. The HOB cells were seeded to the dendrimer coated substrates and spread similarly on the polycationic, the polyanionic and on the control substrates (Au coated glass and the petri dish plastic). After 24 hours, most of the cells had adopted their typical, stretched shape and initiated cell-cell contact. These contacts are vital for their survival and are usually made within the first few days.

The cell proliferation was followed until a confluence of $80-100 \%$. After the first few days, the cells started to show a different behaviour on the samples coated with positively charged dendrimers 6-G $\mathbf{G}_{\mathbf{1}}$ (Fig. 2). On the negatively charged dendrimers $\mathbf{7}-\mathbf{G}_{\mathbf{1}}$ as well as on the control substrates, the cells attached, stretched and proliferated normally. On the positively charged dendrimers $\mathbf{6}-\mathbf{G}_{\mathbf{1}}$, however, the cells proliferated less, resulting in many rounded cells and a low surface coverage. The rounded cells were probably dead cells, which concurs with the decreased proliferation rate. A few rounded cells were observed on the other samples (polyanionic $\mathbf{7}-\mathbf{G}_{\mathbf{1}}$ and control), but most of them spread again. This is a common process and is related to mitosis. Moreover, on the positively charged dendrimers $\mathbf{6}-\mathbf{G}_{\mathbf{1}}$ it was observed that all cells were retracting on longer time scales.

The microscopy images of the cells on positively charged dendrimer have been studied in more detail for the visualization of the dead cells (Fig. 3). Most cells died through apoptosis ("programmed" cell death), rather than necrosis (traumatic cell death). It was possible to observe the main apoptotic hallmarks by their appearance: chromatin condensation (3A), cell retraction $(3 \mathrm{~B}-3 \mathrm{C})$, membrane blebbing $(3 \mathrm{C})$ and the final phase where apoptotic bodies are formed (3C-3D). Cell shrinkage manifests itself with an irregular cell shape and shady areas around the cells. Membrane blebbing is an advanced form of cell shrinkage, where as a result the membrane starts to deform heavily, showing large quasi-spherical protrusions. It manifests itself as small blobs attached to the cell. ${ }^{34}$ Apoptotic bodies are the leftovers of the entire process and can be identified under the microscope (phase contrast) as condensed, ring-like features. 

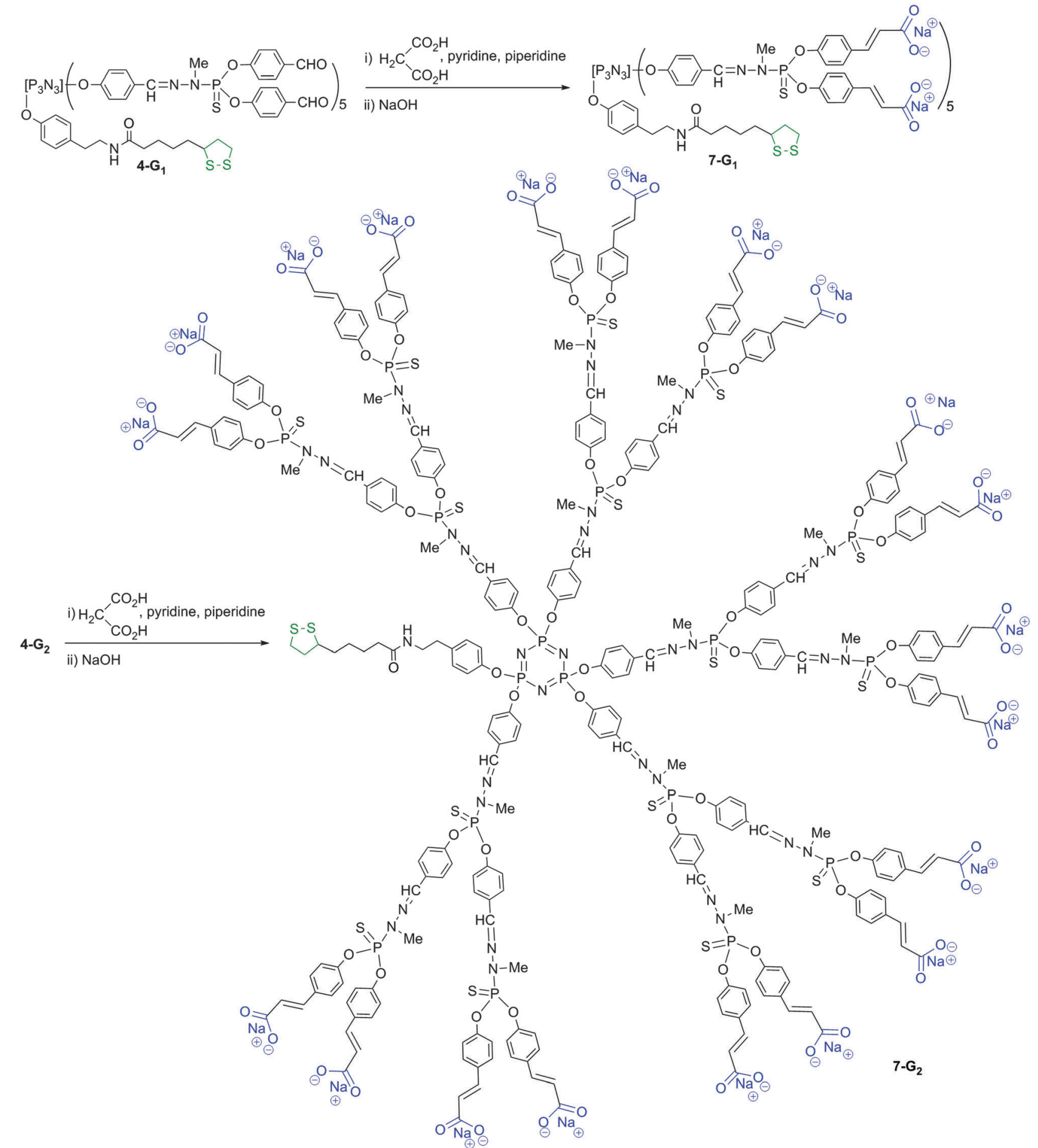

Scheme 4 Synthesis of water-soluble bifunctional dendrimers having one dithiolane function at the core, and $10\left(\mathbf{7}-\mathbf{G}_{1}\right)$ or $20\left(\mathbf{7}-\mathbf{G}_{2}\right)$ ammonium terminal groups.

Fig. 3a and $\mathrm{b}$ were obtained after staining cells with DAPI (4',6-diamidino-2-phenylindole dihydrochloride), which selectively reveals the location of the genetic material. By overlaying the obtained fluorescence images with the regular microscopy images, it was possible to distinguish between healthy cells (nucleus stained blue) and apoptotic cells (diffuse blue stain throughout the cell, Fig. 3b) and to recognize apoptotic hallmarks such as chromatin condensation and breakdown of the nuclear envelope.

The proliferation behaviour and health status of the cells have been quantified in terms of cell viability (Fig. 4A). The viability was determined as the ratio between the number of 

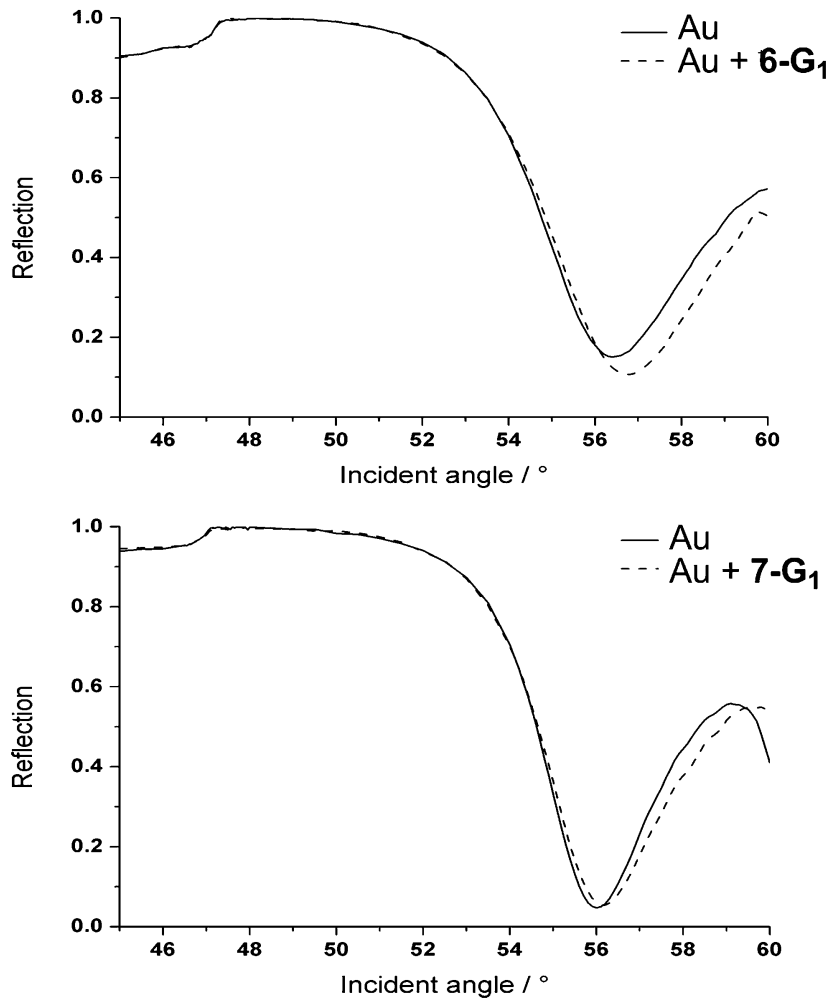

Fig. 1 SPR angular scan of gold samples. Up: with and without a $\mathbf{6}-\mathbf{G}_{1}$ coating; down: with and without a $7-\mathrm{G}_{1}$ coating.
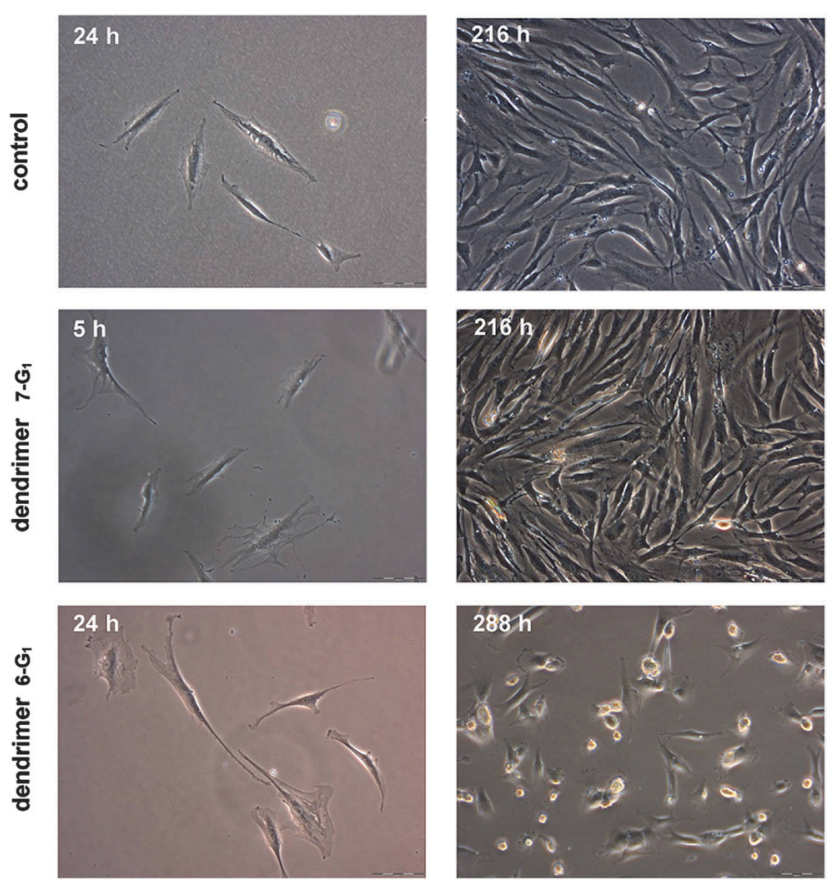

Fig. $2 \mathrm{HOB}$ cell proliferation on control, polyanionic $\left(7-\mathrm{G}_{1}\right)$ and polycationic $\left(6-G_{1}\right)$ samples at different stages.

living and total cells. A significant difference was observed between cells that grew on polycationic $\mathbf{6}-\mathbf{G}_{\mathbf{1}}$ or on polyanionic 7-G $\mathbf{G}_{\mathbf{1}}$ dendrimers. For each sample, values obtained for cells
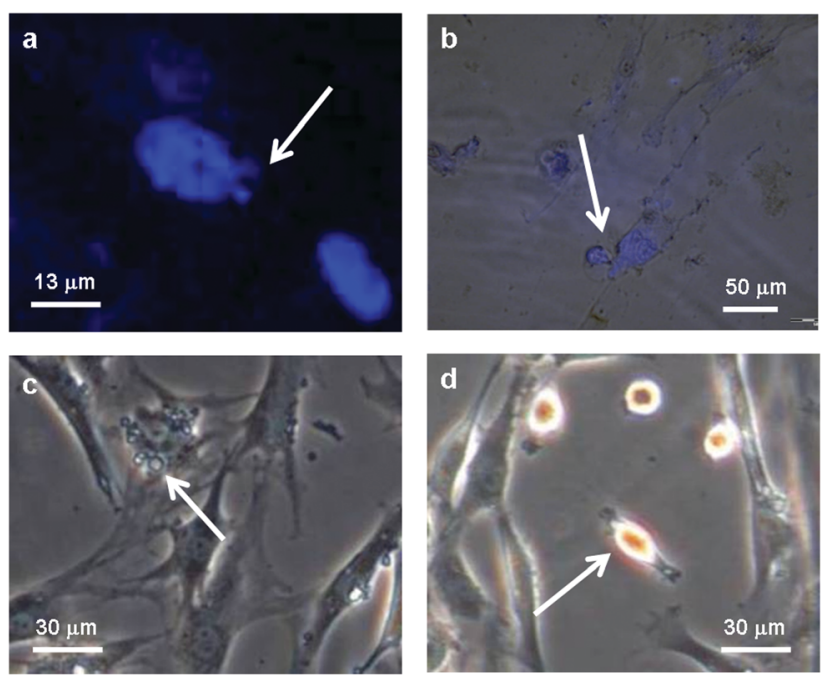

Fig. 3 Hallmarks of apoptosis among HOB cells were only found on positively charged dendrimers $\left(6-G_{1}\right)$. (a) Fluorescence image of a DAPI stained cell nucleus; (b) fluorescence and optical microscopy overlay image of a DAPI stained cell; (c) and (d) optical microscopy of cells. All images were recorded after approximately 280 hours.
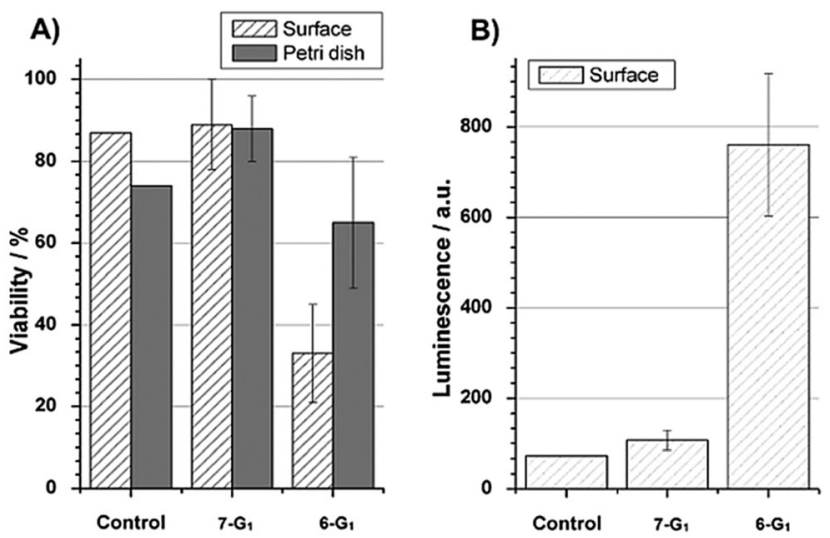

Fig. 4 Proliferation and apoptosis quantified on different dendrimer (negatively charged $\mathbf{7 -} \mathrm{G}_{1}$; positively charged $\mathbf{6}-\mathrm{G}_{1}$ ) coated surfaces: (A) viability, (B) caspase $3 / 7$ activity assay. These values have been obtained after approximately 280 hours of cell adhesion and proliferation.

adhered on the petri dish plastic served as a positive internal reference. Cells on polyanionic dendrimers $\mathbf{7}-\mathbf{G}_{\mathbf{1}}$ and positive control samples showed a very similar behaviour. This indicates that polyanionic dendrimers $\mathbf{7}-\mathbf{G}_{\mathbf{1}}$ did not affect $\mathrm{HOB}$ cell growth as compared to any reference sample. In contrast, polycationic dendrimer $\mathbf{6}^{-\mathbf{G}_{\mathbf{1}}}$ coatings had cytotoxic effects, resulting in a decreased cell number and viability.

A caspase $3 / 7$ specific assay was performed, where the luminescence of Luciferase directly reflects the presence and/or activity of the caspases 3 and 7 (Fig. 4B). These enzymes are only active when a cell undergoes apoptosis. The polyanionic dendrimers $\mathbf{7}-\mathbf{G}_{\mathbf{1}}$ and the control substrates showed similar low values, clearly indicating that cells were not apoptotic. The polycationic dendrimers $\mathbf{6}-\mathbf{G}_{\mathbf{1}}$, however, did strongly provoke apoptosis, confirming the microscopy observations. 
Water-soluble positively charged dendrimers (polyamido amine type) and linear polymers have been described to induce apoptosis among many cell types, ${ }^{35,36}$ mostly through uptake by the cells. Polyamidoamine dendrimers and linear polycations were found to diffuse through the cell membrane and to integrate into the mitochondrial membrane. They compromised the integrity of organelles resulting in a sudden cytochrome c release, which indirectly triggers apoptosis. Furthermore, the amine content as well as the amine substitution degree (primary-quaternary) seems to affect the cytotoxicity; higher substitution degrees were found to be more lethal. ${ }^{35,37}$ In contrast to these experiments, the dendrimers in the current study were attached to a solid support. There are only few reports on apoptosis specifically induced by surface coatings. ${ }^{38}$ In general, cells are unaffected by amines or by positively charged surfaces. In fact, cells adhere preferentially to cationic surfaces due to the stronger electrostatic interaction between the surface and the cell membrane. Furthermore, similar dendrimers with diethyl ammonium groups have been electrostatically attached to a substrate and they showed no apoptotic effect on neuronal cells. ${ }^{13}$

Our results are in marked contrast with several previous reports studying the influence of the charges on the behaviour of cells, including osteoblasts. Indeed, a lower osteoblast cell proliferation on $\mathrm{COOH}$-terminated titanium films was observed compared with $\mathrm{NH}_{2}$-terminated titanium films, ${ }^{18}$ and recent observations described in the literature with positively charged polymeric-dendritic poly(lysine)-coated surfaces ${ }^{39}$ also emphasize the positive role of such a surface on the adhesion of cells. However, the topology of dendrimers is different from that of small molecules and of polymers, and it is well-known that subtle changes in the periphery of dendrimers may deeply modify their properties and cytotoxicity. ${ }^{40}$ In the case of phosphorus dendrimers, positively charged dendrimers with the same ammonium terminal groups than $\mathbf{6}-\mathbf{G}_{\mathbf{1}}$ (but without the thioctic arm) have been used in many cases in contact with cells, as transfection agents, ${ }^{29}$ as anti-HIV agents, ${ }^{41}$ as in vivo anti-prion agents, ${ }^{42}$ and as agents against the aggregation of Alzheimer's peptides. ${ }^{43}$ No acute toxicity was observed, except in the case of human mononuclear blood cells, the polycationic dendrimers induce changes in their morphology, and also the loss of cell attachment properties. ${ }^{44}$ Negatively charged phosphorus dendrimers have many properties for modulating in vitro the response of the human immune system, ${ }^{45}$ and have also anti-inflammatory properties in vivo. ${ }^{46}$ Phosphorus dendrimers ending by the same carboxylate groups as those of $\mathbf{7}-\mathbf{G}_{\mathbf{1}}$ have been already used as non-covalent carriers of anti-HIV aminolactitol, ${ }^{47}$ and in vivo for the delivery of an anti-hypertensive drug, ${ }^{48}$ without an acute toxicity effect.

Since only surfaces covered with the polycationic dendrimers 6-G $\mathbf{G}_{\mathbf{1}}$ were cytotoxic to HOB cells, the specific interaction between the surface bound amine groups and the HOB cells caused an activation of the apoptotic pathway. Stronger electrostatic attraction between cells and substrate can be advantageous for cell initial adhesion, but most cells require mobility and cell-cell contact for proper proliferation, which is inhibited by a stronger attraction, and may account for the observed apoptosis.

\section{Conclusions}

Water-soluble generation 1 and generation 2 bifunctional dendrimers with 10 or 20 peripheral charges and one thioctic acid function linked to the core were synthesized and characterized. Only the first generations could be bound to a gold surface via the dithiolane moiety. Such a function is a convenient alternative to classical thiols for interaction with gold, and may find use in other fields, such as the coating of gold nanoparticles, which have many biological applications. ${ }^{49}$ These functionalized gold surfaces were exposed to human osteoblast (HOB) cells and probed for their ability to sustain cell proliferation. Diethylammonium terminated polycationic dendrimers induced apoptosis among HOB cells, probably triggered by the strong attractive electrostatic interaction between the cells and substrate. A caspase $3 / 7$ activity assay confirmed the apoptotic hallmarks observed by optical microscopy. The carboxyl terminated polyanionic derivatives showed no significant effect on the proliferation of HOB cells. The two different dendrimer coatings are thus potential candidates for application in coatings of biomedical devices, if a specific cell response to the coating is required. Implants require strong cell adhesion and good cell proliferation, while other applications require a non-adhesive coating. Contrarily to polymers classically used for such purposes, the high peripheral functionality, the monodispersity and welldefined shape of dendrimers allow for fine-tuning the surface properties, with high reproducibility, as required for ideal cellsurface interactions.

\section{Experimental}

\section{Syntheses of the dendrimers}

All reactions were carried out under an argon atmosphere and in freshly distilled solvents. All column chromatography experiments were carried out with silica gel 60 as the static phase. All starting compounds were purchased from Aldrich, Merck or Fluka and used as received. Solvents were dried and distilled prior to use. The references for NMR are $\mathrm{Me}_{4} \mathrm{Si}$ for ${ }^{1} \mathrm{H}$ and ${ }^{13} \mathrm{C}$ NMR, $\mathrm{H}_{3} \mathrm{PO}_{4}$ (85\% in water) for ${ }^{31} \mathrm{P} \mathrm{NMR}$. The numbering used for NMR assignment is shown in Fig. 5. p-Hydroxybenzaldehyde sodium salt was prepared by ion exchange with $\mathrm{NaH}$. $\mathrm{H}_{2} \mathrm{NNMeP}(\mathrm{S}) \mathrm{Cl}_{2}{ }^{50}$ and compound $3^{28}$ were prepared as published previously.

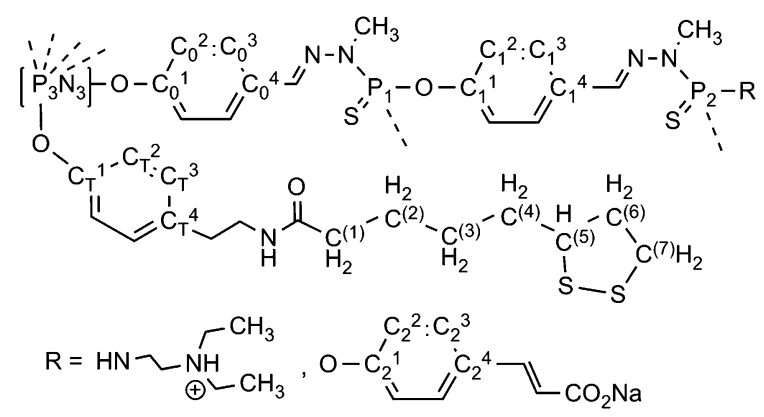

Fig. 5 Numbering used for NMR assignment. 
Compound 1. In a Schlenk flask under an argon atmosphere, thioctic acid (2.509 g, $12.2 \mathrm{mmol}, 1.23 \mathrm{eq}$.$) and DIPEA$ (diisopropylethylamine, $2.2 \mathrm{~mL}, 12.6 \mathrm{mmol}, 1.27$ eq.) were dissolved in $20 \mathrm{~mL}$ of dry dichloromethane and cooled down to $-20{ }^{\circ} \mathrm{C}$. A $20 \mathrm{~mL}$ DMF solution of TBTU (O-(Benzotriazol-1yl)- $N, N, N^{\prime}, N^{\prime}$-tetramethyluronium tetrafluoroborate, $3.634 \mathrm{~g}$, $11.3 \mathrm{mmol}, 1.14$ eq.) was added dropwise and the mixture was stirred for 30 minutes at room temperature. This mixture was added to a $10 \mathrm{~mL}$ DMF suspension of tyramine $(1.356 \mathrm{~g}$, $9.9 \mathrm{mmol}, 1.0$ eq.) and the reaction was completed overnight at room temperature. The solvents were evaporated under reduced pressure. The product was diluted in dichloromethane and washed twice with a saturated aqueous $\mathrm{NaHCO}_{3}$ solution and once with brine and finally dried on $\mathrm{Na}_{2} \mathrm{SO}_{4}$. The crude product was purified by column chromatography $1 \% \mathrm{MeOH}$ in $\mathrm{CHCl}_{3}$ ). This procedure quantitatively yielded the product 1 as a yellow solid. ${ }^{1} \mathrm{H}-\mathrm{NMR}\left(250 \mathrm{MHz}, \mathrm{CDCl}_{3}, \delta\right): 1.39\left(\mathrm{~m}, 2 \mathrm{H}, \mathrm{C}^{(3)} \mathrm{H}_{2}\right)$, $1.62\left(\mathrm{~m}, 4 \mathrm{H}, \mathrm{C}^{(2)} \mathrm{H}_{2}, \mathrm{C}^{(4)} \mathrm{H}_{2}\right), 1.87\left(\mathrm{~m}, 1 \mathrm{H}, \mathrm{C}^{(6)} \mathrm{H}_{2}\right), 2.16\left(\mathrm{t},{ }^{3} J_{\mathrm{HH}}=\right.$ $\left.7.4 \mathrm{~Hz}, 2 \mathrm{H}, \mathrm{C}^{(1)} \mathrm{H}_{2} \mathrm{CO}\right), 2.40\left(\mathrm{~m}, 1 \mathrm{H}, \mathrm{C}^{(6)} \mathrm{H}_{2}\right), 2.72\left(\mathrm{t},{ }^{3} J_{\mathrm{HH}}=\right.$ $\left.7.0 \mathrm{~Hz}, 2 \mathrm{H}, \mathrm{CH}_{2} \mathrm{Ar}\right), 3.12\left(\mathrm{~m}, 2 \mathrm{H}, \mathrm{C}^{(7)} \mathrm{H}_{2} \mathrm{~S}\right), 3.48\left(\mathrm{~m}, 3 \mathrm{H}, \mathrm{C}^{(5)} \mathrm{H}-\mathrm{S}\right.$, $\mathrm{CH}_{2} \mathrm{~N}$ ), 6.06 (br s, $\left.1 \mathrm{H}, \mathrm{NH}\right), 6.81\left(\mathrm{~d},{ }^{3} J_{\mathrm{HH}}=8.4 \mathrm{~Hz}, 2 \mathrm{H}, \mathrm{C}_{\mathrm{T}}{ }^{2} \mathrm{H}\right.$ ), $7.00\left(\mathrm{~d},{ }^{3} \mathrm{~J}_{\mathrm{HH}}=8.4 \mathrm{~Hz}, 2 \mathrm{H}, \mathrm{C}_{\mathrm{T}}{ }^{3} \mathrm{H}\right), 7.98(\mathrm{br} \mathrm{s}, 1 \mathrm{H}, \mathrm{OH}) .{ }^{13} \mathrm{C}\left\{{ }^{1} \mathrm{H}\right\}-$ NMR (75.5 MHz, $\left.\mathrm{CDCl}_{3}, \delta\right): 25.4\left(\mathrm{C}^{(2 / 4)} \mathrm{H}_{2}\right), 28.8\left(\mathrm{C}^{(3)} \mathrm{H}_{2}\right), 34.5$ $\left(\mathrm{C}^{(2 / 4)} \mathrm{H}_{2}\right), 34.7\left(\mathrm{CH}_{2} \mathrm{Ar}\right), 36.5\left(\mathrm{C}^{(1)} \mathrm{H}_{2} \mathrm{CO}\right), 38.5\left(\mathrm{C}^{(7)} \mathrm{H}_{2} \mathrm{~S}\right), 40.3$ $\left(\mathrm{C}^{(6)} \mathrm{H}_{2}\right), 41.0\left(\mathrm{CH}_{2} \mathrm{NH}\right), 56.5\left(\mathrm{C}^{(5)} \mathrm{H}\right), 115.7\left(\mathrm{C}_{\mathrm{T}}^{2}\right), 129.7\left(\mathrm{C}_{\mathrm{T}}^{3,4}\right)$, $155.3\left(\mathrm{C}_{\mathrm{T}}^{1}\right), 173.7$ (NCO).

Compound 2. A solution of compound $1(0.506 \mathrm{~g}$, $1.557 \mathrm{mmol}, 1$ eq.) in THF (50 mL) was added dropwise to a mixture of $\mathrm{N}_{3} \mathrm{P}_{3} \mathrm{Cl}_{6}\left(0.648 \mathrm{~g}, 1.868 \mathrm{mmol}, 1.2 \mathrm{eq}\right.$.) and $\mathrm{Cs}_{2} \mathrm{CO}_{3}$ (1.015 g, $3.114 \mathrm{mmol}, 2.0$ eq.) in THF (200 mL) at $-20{ }^{\circ} \mathrm{C}$. The resulting mixture was allowed to reach slowly room temperature and was stirred overnight. The mixture was concentrated, and then centrifuged. The solution was taken and evaporated to dryness. The product was tentatively purified by column chromatography on silica gel (hexane/ethylacetate as eluent). Compound 2 was obtained as a yellow oil $(0.40 \mathrm{~g}, 0.629 \mathrm{mmol}$, $40 \%$ yield), containing about $5 \%$ of impurities, as detected by ${ }^{31} \mathrm{P}$ and ${ }^{1} \mathrm{H}$ NMR. ${ }^{31} \mathrm{P}\left\{{ }^{1} \mathrm{H}\right\}-\mathrm{NMR}\left(101.3 \mathrm{MHz}, \mathrm{CDCl}_{3}, \delta\right): 12.2$ (pseudo t, ${ }^{2} J_{\mathrm{PP}}=64 \mathrm{~Hz}, \mathrm{PCl}$ ), 22.4 (pseudo d, ${ }^{2} J_{\mathrm{PP}}=64 \mathrm{~Hz}, \mathrm{PCl}_{2}$ ). ${ }^{1} \mathrm{H}-\mathrm{NMR}\left(250 \mathrm{MHz}, \mathrm{CDCl}_{3}, \delta\right): 1.44\left(\mathrm{~m}, 2 \mathrm{H}, \mathrm{C}^{(3)} \mathrm{H}_{2}\right), 1.66(\mathrm{~m}, 4 \mathrm{H}$, $\left.\mathrm{C}^{(2)} \mathrm{H}_{2}, \mathrm{C}^{(4)} \mathrm{H}_{2}\right), 1.90\left(\mathrm{~m}, 1 \mathrm{H}, \mathrm{C}^{(6)} \mathrm{H}_{2}\right), 2.16\left(\mathrm{t},{ }^{3} J_{\mathrm{HH}}=7.4 \mathrm{~Hz}, 2 \mathrm{H}\right.$, $\left.\mathrm{C}^{(1)} \mathrm{H}_{2} \mathrm{CO}\right), 2.46\left(\mathrm{~m}, 1 \mathrm{H}, \mathrm{C}^{(6)} \mathrm{H}_{2}\right), 2.84\left(\mathrm{t},{ }^{3} J_{\mathrm{HH}}=7.0 \mathrm{~Hz}, 2 \mathrm{H}\right.$, $\left.\mathrm{CH}_{2} \mathrm{Ar}\right), 3.15\left(\mathrm{~m}, 2 \mathrm{H}, \mathrm{C}^{(7)} \mathrm{H}_{2} \mathrm{~S}\right), 3.52\left(\mathrm{~m}, 3 \mathrm{H}, \mathrm{C}^{(5)} \mathrm{H}-\mathrm{S}, \mathrm{CH}_{2} \mathrm{~N}\right), 5.68$ (br s, $1 \mathrm{H}, \mathrm{NH}$ ), 7.26 (br s, $4 \mathrm{H}, \mathrm{C}_{\mathrm{T}}{ }^{2,3} \mathrm{H}$ ).

Bifunctional dendrimer $4-\mathbf{G}_{\mathbf{0}}$. A $150 \mathrm{~mL}$ THF solution of 3 (2.82 g, $3.64 \mathrm{mmol}, 1.0$ eq.) and $\mathrm{Cs}_{2} \mathrm{CO}_{3}(1.79 \mathrm{~g}, 5.46 \mathrm{mmol}$, 1.5 eq.) was cooled down to $0{ }^{\circ} \mathrm{C}$. A $20 \mathrm{~mL}$ THF solution of 1 ( $1.30 \mathrm{~g}, 4.00 \mathrm{mmol}, 1.1 \mathrm{eq}$.) was added and the reaction mixture was stirred overnight at room temperature. The mixture was centrifuged ( $30 \mathrm{~min}, 10 \mathrm{k} \mathrm{rpm}$ ), the salts were removed, and the THF was evaporated. The product was purified by column chromatography using an increasing gradient of ethyl acetate/ hexane starting at a $1: 1$ ratio. This yielded the dendrimer $\mathbf{4}-\mathbf{G}_{\mathbf{0}}$ (2.91 g, $2.72 \mathrm{mmol}, 75 \%)$ as a yellow oil. ${ }^{31} \mathrm{P}\left\{{ }^{1} \mathrm{H}\right\}-\mathrm{NMR}(101.3 \mathrm{MHz}$, $\left.\mathrm{CDCl}_{3}, \delta\right): 7.4\left(\mathrm{~m}, \mathrm{~N}_{3} \mathrm{P}_{3}\right) .{ }^{1} \mathrm{H}-\mathrm{NMR}\left(250 \mathrm{MHz}, \mathrm{CDCl}_{3}, \delta\right): 1.41$ $\left(\mathrm{m}, 2 \mathrm{H}, \mathrm{C}^{(3)} \mathrm{H}_{2}\right.$ ), $1.62\left(\mathrm{~m}, 4 \mathrm{H}, \mathrm{C}^{(2)} \mathrm{H}_{2}, \mathrm{C}^{(4)} \mathrm{H}_{2}\right), 1.90\left(\mathrm{~m}, 1 \mathrm{H}, \mathrm{C}^{(6)} \mathrm{H}_{2}\right)$, $2.12\left(\mathrm{t},{ }^{3} \mathrm{~J}_{\mathrm{HH}}=7.4 \mathrm{~Hz}, 2 \mathrm{H}, \mathrm{C}^{(1)} \mathrm{H}_{2} \mathrm{CO}\right), 2.40\left(\mathrm{~m}, 1 \mathrm{H}, \mathrm{C}^{(6)} \mathrm{H}_{2}\right), 2.73$ $\left(\mathrm{t},{ }^{3} J_{\mathrm{HH}}=7.0 \mathrm{~Hz}, 2 \mathrm{H}, \mathrm{CH}_{2} \mathrm{Ar}\right), 3.11\left(\mathrm{~m}, 2 \mathrm{H}, \mathrm{C}^{(7)} \mathrm{H}_{2} \mathrm{~S}\right), 3.50(\mathrm{~m}, 3 \mathrm{H}$, $\mathrm{C}^{(5)} \mathrm{H}-\mathrm{S}, \mathrm{CH}_{2} \mathrm{~N}$ ), 5.81 (br s, $\left.1 \mathrm{H}, \mathrm{NH}\right), 6.82\left(\mathrm{~m}, 2 \mathrm{H}, \mathrm{C}_{\mathrm{T}}{ }^{2} \mathrm{H}\right), 7.02$ $\left(\mathrm{m}, 2 \mathrm{H}, \mathrm{C}_{\mathrm{T}}{ }^{3} \mathrm{H}\right), 7.28\left(\mathrm{~m}, 10 \mathrm{H}, \mathrm{C}_{0}{ }^{2} \mathrm{H}\right), 7.80\left(\mathrm{~m}, 10 \mathrm{H}, \mathrm{C}_{0}{ }^{3} \mathrm{H}\right), 9.95$ (2s, 5H, CHO). ${ }^{13} \mathrm{C}\left\{{ }^{1} \mathrm{H}\right\}-\mathrm{NMR}\left(62.9 \mathrm{MHz} \mathrm{CDCl}_{3}, \delta\right): 25.3$ $\left(\mathrm{C}^{(2 / 4)} \mathrm{H}_{2}\right), 28.9\left(\mathrm{C}^{(3)} \mathrm{H}_{2}\right), 34.6\left(\mathrm{C}^{(2 / 4)} \mathrm{H}_{2}\right), 35.1\left(\mathrm{CH}_{2} \mathrm{Ar}\right), 36.4$ $\left(\mathrm{C}^{(1)} \mathrm{H}_{2} \mathrm{CO}\right), 38.5\left(\mathrm{C}^{(7)} \mathrm{H}_{2} \mathrm{~S}\right), 40.3\left(\mathrm{C}^{(6)} \mathrm{H}_{2}\right), 40.5\left(\mathrm{CH}_{2} \mathrm{NH}\right), 56.4$ $\left(\mathrm{C}^{(5)} \mathrm{H}\right), 120.7\left(\mathrm{C}_{\mathrm{T}}^{2}\right), 121.3\left(\mathrm{C}_{0}^{2}\right), 129.9\left(\mathrm{C}_{\mathrm{T}}^{3}\right), 131.4\left(\mathrm{C}_{0}^{3}\right), 133.7$ $\left(\mathrm{C}_{0}^{4}\right), 136.6\left(\mathrm{C}_{\mathrm{T}}^{4}\right), 154.7\left(\mathrm{C}_{0}{ }^{1}, \mathrm{C}_{\mathrm{T}}{ }^{1}\right), 172.8(\mathrm{NCO}), 190.5$ (CHO).

Bifunctional dendrimer 5-G $\mathbf{G}_{1}$. A $56.7 \mathrm{~mL} 0.24 \mathrm{M}$ solution of $\mathrm{H}_{2} \mathrm{NNMePSCl}_{2}$ (1.26 mmol, 5 eq.) in chloroform was added to a $50 \mathrm{~mL}$ solution of $\mathbf{4}-\mathbf{G}_{\mathbf{0}}$ (2.906 g, $2.72 \mathrm{mmol}, 1.0 \mathrm{eq}$.) in chloroform. After one night the amount of solvent was reduced to a few milliliters and then added dropwise to a large amount of pentane. The product precipitated readily and the solvent was filtered off by means of a canula. This process was repeated three times. Dendrimer 5-G $\mathbf{1}$ was obtained as a white (pale yellow) solid with a yield of $4.68 \mathrm{~g}(2.50 \mathrm{mmol}, 92 \%) .{ }^{31} \mathrm{P}\left\{{ }^{1} \mathrm{H}\right\}-\mathrm{NMR}(121.5 \mathrm{MHz}$, $\left.\mathrm{CDCl}_{3}, \delta\right): 8.3\left(\mathrm{~m}, \mathrm{~N}_{3} \mathrm{P}_{3}\right), 62.4 / 62.6\left(\mathrm{~s}, \mathrm{P}_{1}\right) .{ }^{1} \mathrm{H}-\mathrm{NMR}(300 \mathrm{MHz}$, $\left.\mathrm{CDCl}_{3}, \delta\right): 1.41\left(\mathrm{~m}, 2 \mathrm{H}, \mathrm{C}^{(3)} \mathrm{H}_{2}\right), 1.63\left(\mathrm{~m}, 4 \mathrm{H}, \mathrm{C}^{(2)} \mathrm{H}_{2}, \mathrm{C}^{(4)} \mathrm{H}_{2}\right), 1.85$ $\left(\mathrm{m}, 1 \mathrm{H}, \mathrm{C}^{(6)} \mathrm{H}_{2}\right), 2.12\left(\mathrm{t},{ }^{3} \mathrm{~J}_{\mathrm{HH}}=7.2 \mathrm{~Hz}, 2 \mathrm{H}, \mathrm{C}^{(1)} \mathrm{H}_{2} \mathrm{CO}\right), 2.45(\mathrm{~m}, 1 \mathrm{H}$, $\left.\mathrm{C}^{(6)} \mathrm{H}_{2}\right), 2.77\left(\mathrm{t},{ }^{3} \mathrm{~J}_{\mathrm{HH}}=7.2 \mathrm{~Hz}, 2 \mathrm{H}, \mathrm{CH}_{2} \mathrm{Ar}\right), 3.14\left(\mathrm{~m}, 17 \mathrm{H}, \mathrm{C}^{(7)} \mathrm{H}_{2} \mathrm{~S}\right.$, $\left.\mathrm{P}_{1}-\mathrm{N}-\mathrm{CH}_{3}\right), 3.45\left(\mathrm{~m}, 3 \mathrm{H}, \mathrm{C}^{(5)} \mathrm{H}-\mathrm{S}, \mathrm{CH}_{2} \mathrm{~N}\right), 5.64$ (br s, $1 \mathrm{H}, \mathrm{NH}$ ), 6.91-7.06 (m, 12H, C $\left.{ }_{\mathrm{T}}{ }^{2} \mathrm{H}, \mathrm{C}_{0}{ }^{2} \mathrm{H}\right)$, 7.58-7.65 (m, 12H, $\left.\mathrm{C}_{\mathrm{T}}{ }^{3} \mathrm{H}, \mathrm{C}_{0}{ }^{3} \mathrm{H}\right)$, $7.70(\mathrm{~s}, 5 \mathrm{H}, \mathrm{CH}=\mathrm{N}) .{ }^{13} \mathrm{C}\left\{{ }^{1} \mathrm{H}\right\}-\mathrm{NMR}\left(75.5 \mathrm{MHz}, \mathrm{CDCl}_{3}, \delta\right): 25.4$ $\left(\mathrm{C}^{(2 / 4)} \mathrm{H}_{2}\right), 28.9\left(\mathrm{C}^{(3)} \mathrm{H}_{2}\right), 32.0\left(\mathrm{~d},{ }^{2} J_{\mathrm{CP}}=13.2 \mathrm{~Hz}, \mathrm{P}_{1}-\mathrm{N}-\mathrm{CH}_{3}\right), 34.6$ $\left(\mathrm{C}^{(2 / 4)} \mathrm{H}_{2}\right)$, $35.2\left(\mathrm{CH}_{2} \mathrm{Ar}\right), 36.4\left(\mathrm{C}^{(1)} \mathrm{H}_{2}\right), 38.5\left(\mathrm{C}^{(7)} \mathrm{H}_{2} \mathrm{~S}\right), 40.3\left(\mathrm{C}^{(6)} \mathrm{H}_{2}\right)$, $40.7\left(\mathrm{CH}_{2} \mathrm{NH}\right), 56.5\left(\mathrm{C}^{(5)} \mathrm{H}\right), 121.1\left(\mathrm{C}_{\mathrm{T}}^{2}\right), 121.4\left(\mathrm{C}_{0}^{2}\right), 128.6\left(\mathrm{C}_{0}^{3}\right)$, $129.7\left(\mathrm{C}_{\mathrm{T}}^{3}\right), 131.3\left(\mathrm{C}_{0}{ }^{4}\right), 135.9\left(\mathrm{C}_{\mathrm{T}}^{4}\right), 140.8\left(\mathrm{br} \mathrm{d},{ }^{3} J_{\mathrm{CP}}=20.1 \mathrm{~Hz}\right.$, $\left.\mathrm{CH}=\mathrm{N}-\mathrm{N}-\mathrm{P}_{1}\right), 149.0\left(\mathrm{C}_{\mathrm{T}}^{1}\right), 151.7\left(\mathrm{C}_{0}^{1}\right), 173.0(\mathrm{NCO})$.

Bifunctional dendrimer 6-G $\mathbf{G}_{\mathbf{1}} \cdot N, N$-Diethylethylenediamine (765 $\mu \mathrm{L}, 5.35 \mathrm{mmol}, 10$ eq.) was added dropwise to a $150 \mathrm{~mL}$ THF solution of $\mathbf{5}-\mathbf{G}_{\mathbf{1}}(1.002 \mathrm{~g}, 5.36 \mathrm{mmol}, 1.0 \mathrm{eq}$.). The reaction was left to stir at room temperature overnight. A white solid appeared during the reaction. The precipitate was washed with dry THF and diethylether and was lyophilized. Dendrimer 6-G was obtained as a white powder (1.226 g, $405 \mu \mathrm{mol}, 76 \%)$. ${ }^{31} \mathrm{P}\left\{{ }^{1} \mathrm{H}\right\}$-NMR (121.5 MHz, $\left.\mathrm{CD}_{3} \mathrm{OD}, \delta\right): 8.5\left(\mathrm{~s}, \mathrm{~N}_{3} \mathrm{P}_{3}\right), 70.4\left(\mathrm{~s}, \mathrm{P}_{1}\right)$. ${ }^{1} \mathrm{H}-\mathrm{NMR}\left(300 \mathrm{MHz}, \mathrm{CD}_{3} \mathrm{OD}, \delta\right): 1.26\left(\mathrm{t},{ }^{3} J_{\mathrm{HH}}=7.2 \mathrm{~Hz}\right.$, about $10 \mathrm{H}$, $\left.\mathrm{NCH}_{2} \mathrm{CH}_{3}\right), 1.33\left(\mathrm{t},{ }^{3} \mathrm{~J}_{\mathrm{HH}}=7.2 \mathrm{~Hz}\right.$, about $\left.50 \mathrm{H}, \mathrm{N}^{+} \mathrm{CH}_{2} \mathrm{CH}_{3}\right), 1.40$ $\left(\mathrm{m}, 2 \mathrm{H}, \mathrm{C}^{(3)} \mathrm{H}_{2}\right), 1.66\left(\mathrm{~m}, 4 \mathrm{H}, \mathrm{C}^{(2)} \mathrm{H}_{2}, \mathrm{C}^{(4)} \mathrm{H}_{2}\right), 1.85(\mathrm{~m}, 1 \mathrm{H}$, $\left.\mathrm{C}^{(6)} \mathrm{H}_{2}\right), 2.16\left(\mathrm{t},{ }^{3} J_{\mathrm{HH}}=7.2 \mathrm{~Hz}, 2 \mathrm{H}, \mathrm{C}^{(1)} \mathrm{H}_{2} \mathrm{CO}\right), 2.43(\mathrm{~m}, 1 \mathrm{H}$, $\left.\mathrm{C}^{(6)} \mathrm{H}_{2}\right), 2.78\left(\mathrm{t},{ }^{3} J_{\mathrm{HH}}=7.2 \mathrm{~Hz}, 2 \mathrm{H}, \mathrm{CH}_{2} \mathrm{Ar}\right), 2.97\left(\mathrm{q},{ }^{3} J_{\mathrm{HH}}=7.2 \mathrm{~Hz}\right.$, about $\left.6 \mathrm{H}, \mathrm{NCH}_{2} \mathrm{CH}_{3}\right), 3.12\left(\mathrm{~m}, 2 \mathrm{H}, \mathrm{C}^{(7)} \mathrm{H}_{2} \mathrm{~S}\right), 3.15-3.50(\mathrm{~m}, 91 \mathrm{H}$, $\left.\mathrm{C}^{(5)} \mathrm{H}-\mathrm{S}, \mathrm{CH}_{2} \mathrm{~N}, \mathrm{P}_{1}-\mathrm{N}-\mathrm{CH}_{3}, \mathrm{~N}^{+} \mathrm{CH}_{2} \mathrm{CH}_{3}\right), 6.82\left(\mathrm{~m}, 2 \mathrm{H}, \mathrm{C}_{\mathrm{T}}{ }^{2} \mathrm{H}\right)$, 7.00-7.11 (m, $\left.12 \mathrm{H}, \mathrm{C}_{\mathrm{T}}{ }^{3} \mathrm{H}, \mathrm{C}_{0}{ }^{2} \mathrm{H}\right), 7.70-7.81\left(\mathrm{~m}, 15 \mathrm{H}, \mathrm{C}_{0}{ }^{3} \mathrm{H}\right.$, $\left.\mathrm{CH}=\mathrm{N}-\mathrm{N}-\mathrm{P}_{1}\right) . \quad{ }^{13} \mathrm{C}\left\{{ }^{1} \mathrm{H}\right\}-\mathrm{NMR} \quad\left(75.5 \mathrm{MHz}, \quad \mathrm{CD}_{3} \mathrm{OD}, \quad \delta\right): \quad 7.8$ $\left(\mathrm{N}^{+} \mathrm{CH}_{2} \mathrm{CH}_{3}\right), 9.0\left(\mathrm{NCH}_{2} \mathrm{CH}_{3}\right), 25.4\left(\mathrm{C}^{(2 / 4)} \mathrm{H}_{2}\right), 28.5\left(\mathrm{C}^{(3)} \mathrm{H}_{2}\right), 31.4$ $\left(2 \mathrm{~d},{ }^{2} J_{\mathrm{CP}}=10.6 \mathrm{~Hz}, \mathrm{P}_{1}-\mathrm{N}-\mathrm{CH}_{3}\right), 34.4\left(\mathrm{C}^{(2 / 4)} \mathrm{H}_{2}\right), 35.5\left(\mathrm{CH}_{2} \mathrm{Ar}\right)$, $36.2\left(\mathrm{C}^{(1)} \mathrm{H}_{2} \mathrm{CO}, \quad \mathrm{CH}_{2}-\mathrm{N}-\mathrm{P}_{1}\right), \quad 38.0 \quad\left(\mathrm{C}^{(7)} \mathrm{H}_{2} \mathrm{~S}\right), \quad 40.0 \quad\left(\mathrm{C}^{(6)} \mathrm{H}_{2}\right)$, $40.4\left(\mathrm{CH}_{2} \mathrm{NHCO}\right), 49.0\left(\mathrm{~N}-\mathrm{CH}_{2} \mathrm{CH}_{3}\right), 52.2\left(\mathrm{~d},{ }^{3} J_{\mathrm{CP}}=6.9 \mathrm{~Hz}\right.$, $\left.\mathrm{P}_{1}-\mathrm{N}-\mathrm{CH}_{2} \mathrm{CH}_{2}\right), \quad 56.5\left(\mathrm{C}^{(5)} \mathrm{H}-\mathrm{S}\right), \quad 120.5 \quad\left(\mathrm{C}_{\mathrm{T}}^{2}\right), \quad 120.9 \quad\left(\mathrm{C}_{0}^{2}\right)$, $128.0\left(\mathrm{C}_{0}^{3}\right), 129.7\left(\mathrm{C}_{\mathrm{T}}^{3}\right), 133.2\left(\mathrm{C}_{0}^{4}\right), 136.4\left(\mathrm{C}_{\mathrm{T}}{ }^{4}\right), 137.7(\mathrm{~m}$, $\left.\mathrm{CH}=\mathrm{N}-\mathrm{N}-\mathrm{P}_{1}\right), 150.8\left(\mathrm{~m}, \mathrm{C}_{0}{ }^{1}, \mathrm{C}_{\mathrm{T}}{ }^{1}\right), 174.5(\mathrm{NCO})$.

Bifunctional dendrimer $\mathbf{4}-\mathbf{G}_{\mathbf{1}}$. In a Schlenk tube under an argon atmosphere were mixed $4.68 \mathrm{~g}$ of $\mathbf{5}-\mathbf{G}_{\mathbf{1}}(2.50 \mathrm{mmol}$, 
1.0 eq.), $7.00 \mathrm{~g}$ of $p$-hydroxybenzaldehyde (57.4 mmol, 23 eq., excess to accelerate the reaction) and $16.25 \mathrm{~g}$ of $\mathrm{Cs}_{2} \mathrm{CO}_{3}$ (50 mmol, 20 eq.) and dissolved in $250 \mathrm{~mL}$ of THF. The reaction mixture was stirred overnight at room temperature. The mixture was centrifuged, concentrated under reduced pressure, precipitated from pentane/ether and finally put on a small silicagel column to separate the product from the excessive amount of $p$-hydroxybenzaldehyde. This procedure yielded $5.97 \mathrm{~g}(88 \%)$ of dendrimer $\mathbf{4}_{\mathbf{-}} \mathbf{G}_{\mathbf{1}}$ in the form of a pale yellow solid. ${ }^{31} \mathrm{P}\left\{{ }^{1} \mathrm{H}\right\}-\mathrm{NMR}$ (101.3 MHz, $\left.\mathrm{CDCl}_{3}, \delta\right): 8.2\left(\mathrm{~s}, \mathrm{~N}_{3} \mathrm{P}_{3}\right), 60.4\left(\mathrm{~s}, \mathrm{P}_{1}\right) .{ }^{1} \mathrm{H}-\mathrm{NMR}$ $\left(250 \mathrm{MHz}, \mathrm{CDCl}_{3}, \delta\right): 1.38\left(\mathrm{~m}, 2 \mathrm{H}, \mathrm{C}^{(3)} \mathrm{H}_{2}\right), 1.57\left(\mathrm{~m}, 4 \mathrm{H}, \mathrm{C}^{(4)} \mathrm{H}_{2}\right.$, $\left.\mathrm{C}^{(2)} \mathrm{H}_{2}\right), 1.86\left(\mathrm{~m}, 1 \mathrm{H}, \mathrm{C}^{(6)} \mathrm{H}_{2}\right), 2.06\left(\mathrm{~m}, 2 \mathrm{H}, \mathrm{CH}_{2} \mathrm{CO}\right), 2.38(\mathrm{~m}, 1 \mathrm{H}$, $\left.\mathrm{C}^{(6)} \mathrm{H}_{2}\right), 2.70\left(\mathrm{~m}, 2 \mathrm{H}, \mathrm{CH}_{2} \mathrm{Ar}\right), 3.06\left(\mathrm{~m}, 2 \mathrm{H}, \mathrm{C}^{(7)} \mathrm{H}_{2} \mathrm{~S}\right), 3.36(\mathrm{~m}, 18 \mathrm{H}$, $\left.\mathrm{C}^{(5)} \mathrm{H}-\mathrm{S}, \mathrm{CH}_{2} \mathrm{NH}, \mathrm{P}_{1}-\mathrm{N}-\mathrm{CH}_{3}\right), 5.98(\mathrm{~s}, 1 \mathrm{H}, \mathrm{NH}), 6.96(\mathrm{~m}, 2 \mathrm{H}$, $\left.\mathrm{C}_{\mathrm{T}}{ }^{2} \mathrm{H}\right), 7.03\left(\mathrm{~m}, 12 \mathrm{H}, \mathrm{C}_{0}{ }^{2} \mathrm{H}, \mathrm{C}_{\mathrm{T}}{ }^{3} \mathrm{H}\right), 7.34\left(\mathrm{~m}, 20 \mathrm{H}, \mathrm{C}_{1}{ }^{2} \mathrm{H}\right), 7.56$ $\left(\mathrm{m}, 10 \mathrm{H}, \mathrm{C}_{0}{ }^{3} \mathrm{H}\right), 7.65(\mathrm{~s}, 3 \mathrm{H}, \mathrm{CH}=\mathrm{N}-\mathrm{N}), 7.67(\mathrm{~s}, 2 \mathrm{H}, \mathrm{CH}=\mathrm{N}-\mathrm{N})$, $7.81\left(\mathrm{~m}, 20 \mathrm{H}, \mathrm{C}_{1}{ }^{3} \mathrm{H}\right), 9.93(\mathrm{~s}, 10 \mathrm{H}, \mathrm{CHO}) .{ }^{13} \mathrm{C}\left\{{ }^{1} \mathrm{H}\right\}-\mathrm{NMR}(62.9 \mathrm{MHz}$, $\left.\mathrm{CDCl}_{3}, \delta\right): 25.4\left(\mathrm{C}^{(2 / 4)} \mathrm{H}_{2}\right), 28.8\left(\mathrm{C}^{(3)} \mathrm{H}_{2}\right), 32.8\left(\mathrm{~d},{ }^{2} J_{\mathrm{CP}}=12.8 \mathrm{~Hz}\right.$, $\left.\mathrm{P}_{1}-\mathrm{N}-\mathrm{CH}_{3}\right), 34.6\left(\mathrm{C}^{(2 / 4)} \mathrm{H}_{2}\right), 35.0\left(\mathrm{CH}_{2} \mathrm{Ar}\right), 36.2\left(\mathrm{C}^{(1)} \mathrm{H}_{2}\right), 38.4$ $\left(\mathrm{C}^{(7)} \mathrm{H}_{2} \mathrm{~S}\right), 40.2\left(\mathrm{C}^{(6)} \mathrm{H}_{2}\right), 40.5\left(\mathrm{CH}_{2} \mathrm{NH}\right), 56.5\left(\mathrm{C}^{(5)} \mathrm{H}-\mathrm{S}\right), 121.0$ $\left(\mathrm{C}_{\mathrm{T}}{ }^{2}\right), 121.4\left(\mathrm{C}_{0}{ }^{2}\right), 121.8\left(\mathrm{~d},{ }^{3} J_{\mathrm{CP}}=6.8 \mathrm{~Hz}, \mathrm{C}_{1}{ }^{2}\right), 128.3\left(\mathrm{C}_{1}^{3}\right)$, $129.7\left(\mathrm{C}_{\mathrm{T}}{ }^{3}\right), 131.4\left(\mathrm{C}_{1}{ }^{4}\right), 131.8\left(\mathrm{C}_{0}{ }^{3}\right), 133.7\left(\mathrm{C}_{0}{ }^{4}\right), 135.8\left(\mathrm{C}_{\mathrm{T}}{ }^{4}\right)$, $139.7\left(\mathrm{~d},{ }^{3} J_{\mathrm{CP}}=13.4 \mathrm{~Hz}, \mathrm{CH}=\mathrm{N}-\mathrm{N}-\mathrm{P}_{1}\right), 151.5\left(\mathrm{~d},{ }^{2} J_{\mathrm{CP}}=7.0 \mathrm{~Hz}\right.$, $\left.\mathrm{C}_{0}{ }^{1}, \mathrm{C}_{\mathrm{T}}{ }^{1}\right), 155.0\left(\mathrm{~d},{ }^{2} J_{\mathrm{CP}}=7.0 \mathrm{~Hz}, \mathrm{C}_{1}{ }^{1}\right), 172.8(\mathrm{NCO}), 190.7(\mathrm{CHO})$.

Bifunctional dendrimer $\mathbf{7}-\mathbf{G}_{\mathbf{1}}$. Compound $\mathbf{4}-\mathbf{G}_{\mathbf{1}}(1.00 \mathrm{~g}$, $0.367 \mathrm{mmol}, 1.0 \mathrm{eq}.), 0.95 \mathrm{~g}$ of malonic acid $(9.17 \mathrm{mmol}$, 25 eq.) and $45 \mu \mathrm{L}$ of freshly distilled (on $\mathrm{CaH}_{2}$ ) piperidine (0.459 mmol, 1.25 eq.) were dissolved in $15 \mathrm{~mL}$ of freshly distilled pyridine (on $\mathrm{CaH}_{2}$ ) and left to stir overnight at $95{ }^{\circ} \mathrm{C}$. The mixture was then refluxed for 15 minutes more to remove the $\mathrm{CO}_{2}$ and let to cool down before precipitating it on ice cooled $\mathrm{HCl}(37 \%)$. The precipitate was subsequently washed with water ( 3 times) and ether ( 2 times) and dried under the vacuum. In order to obtain the sodium salt, the product was poured into water and $12.25 \mathrm{~mL}$ of $0.1996 \mathrm{M} \mathrm{NaOH}(\mathrm{aq})$ (excess) was added dropwise yielding a slightly turbid solution. The overall yield was $0.811 \mathrm{~g}$ of the sodium salt $\mathbf{7}-\mathbf{G}_{\mathbf{1}}(241 \mu \mathrm{mol}$, $66 \%)$. The NMR spectra were recorded before ion exchange (COOH terminated dendrimer). ${ }^{31} \mathrm{P}\left\{{ }^{1} \mathrm{H}\right\}-\mathrm{NMR}(121.5 \mathrm{MHz}$, DMSO- $\left.d_{6}, \delta\right): 8.4\left(\mathrm{~s}, \mathrm{~N}_{3} \mathrm{P}_{3}\right), 62.0\left(\mathrm{~s}, \mathrm{P}_{1}\right) .{ }^{1} \mathrm{H}-\mathrm{NMR}(300 \mathrm{MHz}$, DMSO- $\left.d_{6}, \delta\right): 1.22\left(\mathrm{~m}, 2 \mathrm{H}, \mathrm{C}^{(3)} \mathrm{H}_{2}\right), 1.42\left(\mathrm{~m}, 4 \mathrm{H}, \mathrm{C}^{(4)} \mathrm{H}_{2}, \mathrm{C}^{(2)} \mathrm{H}_{2}\right)$, $1.75\left(\mathrm{~m}, 1 \mathrm{H}, \mathrm{C}^{(6)} \mathrm{H}_{2}\right), 1.96\left(\mathrm{~m}, 2 \mathrm{H}, \mathrm{CH}_{2} \mathrm{CO}\right), 2.29\left(\mathrm{~m}, 1 \mathrm{H}, \mathrm{C}^{(6)} \mathrm{H}_{2}\right)$, $2.58\left(\mathrm{~m}, 2 \mathrm{H}, \mathrm{CH}_{2} \mathrm{Ar}\right), 3.04\left(\mathrm{~m}, 2 \mathrm{H}, \mathrm{C}^{(7)} \mathrm{H}_{2} \mathrm{~S}\right), 3.27-3.41(\mathrm{~m}$, $18 \mathrm{H}, \mathrm{C}^{(5)} \mathrm{H}-\mathrm{S}, \mathrm{CH}_{2} \mathrm{NH}, \mathrm{P}_{1}-\mathrm{N}-\mathrm{CH}_{3}$ ), 5.35 (br s, $\left.1 \mathrm{H}, \mathrm{NH}\right), 6.43$ $\left(\mathrm{d},{ }^{3} \mathrm{~J}_{\mathrm{HH}}=15.9 \mathrm{~Hz}, 10 \mathrm{H}, \mathrm{CH}=\mathrm{CHCO}_{2}\right), 6.80\left(\mathrm{~m}, 2 \mathrm{H}, \mathrm{C}_{\mathrm{T}}{ }^{2} \mathrm{H}\right), 7.03$ $\left(\mathrm{m}, 12 \mathrm{H}, \mathrm{C}_{\mathrm{T}}^{3} \mathrm{H}, \mathrm{C}_{0}{ }^{2} \mathrm{H}\right), 7.16\left(\mathrm{~m}, 20 \mathrm{H}, \mathrm{C}_{1}{ }^{2} \mathrm{H}\right), 7.19\left(\mathrm{~d},{ }^{3} J_{\mathrm{HH}}=\right.$ $\left.15.9 \mathrm{~Hz}, 10 \mathrm{H}, \mathrm{CH}=\mathrm{CHCO}_{2}\right), 7.61\left(\mathrm{~m}, 30 \mathrm{H}, \mathrm{C}_{0}{ }^{3} \mathrm{H}, \mathrm{C}_{1}{ }^{3} \mathrm{H}\right), 7.85$ $(\mathrm{s}, 3 \mathrm{H}, \mathrm{CH}=\mathrm{N}-\mathrm{N}), 7.91(\mathrm{~s}, 2 \mathrm{H}, \mathrm{CH}=\mathrm{N}-\mathrm{N}), 12.4(\mathrm{~s}, 10 \mathrm{H}, \mathrm{COOH})$. ${ }^{13} \mathrm{C}\left\{{ }^{1} \mathrm{H}\right\}$-NMR (75.5 MHz, DMSO- $\left.d_{6}, \delta\right): 25.5\left(\mathrm{C}^{(2 / 4)} \mathrm{H}_{2}\right), 28.8$ $\left(\mathrm{C}^{(3)} \mathrm{H}_{2}\right), 33.4\left(2 \mathrm{~d},{ }^{2} J_{\mathrm{CP}}=11.9 \mathrm{~Hz}, \mathrm{P}_{1}-\mathrm{N}-\mathrm{CH}_{3}\right), 34.6\left(\mathrm{C}^{(2 / 4)} \mathrm{H}_{2}\right)$, $34.9\left(\mathrm{CH}_{2} \mathrm{Ar}\right), 35.7\left(\mathrm{C}^{(1)} \mathrm{H}_{2}\right), 38.5\left(\mathrm{C}^{(7)} \mathrm{H}_{2} \mathrm{~S}\right), 56.5\left(\mathrm{C}^{(5)} \mathrm{H}-\mathrm{S}\right), 119.9$ $(\mathrm{Ar}-\mathrm{CH}=\mathrm{CH}), 120.7\left(\mathrm{C}_{\mathrm{T}}{ }^{2}\right), 121.4\left(\mathrm{C}_{0}{ }^{2}\right), 121.8\left(\mathrm{~d},{ }^{3} J_{\mathrm{CP}}=4.1 \mathrm{~Hz}\right.$, $\left.\mathrm{C}_{1}{ }^{2}\right), 128.7\left(\mathrm{C}_{0}{ }^{3}\right), 129.0\left(\mathrm{C}_{\mathrm{T}}{ }^{3}\right), 130.2\left(\mathrm{C}_{1}{ }^{3}\right), 132.2\left(\mathrm{C}_{1}{ }^{4}\right), 132.4\left(\mathrm{C}_{0}{ }^{4}\right)$, $137.2\left(\mathrm{C}_{\mathrm{T}}{ }^{4}\right), 141.1(\mathrm{CH}=\mathrm{N}-\mathrm{N}), 143.1(\mathrm{Ar}-\mathrm{CH}=\mathrm{CH}), 148.4\left(\mathrm{C}_{\mathrm{T}}{ }^{1}\right)$, $151.0\left(\mathrm{C}_{0}{ }^{1}\right), 151.7\left(\mathrm{C}_{1}{ }^{1}\right), 167.9(\mathrm{COOH}), 172.3(\mathrm{NCO}) .\left(\mathrm{C}^{(6)} \mathrm{H}_{2}\right.$ and $\mathrm{CH}_{2} \mathrm{NH}$ hidden by DMSO).
Bifunctional dendrimer $\mathbf{5}-\mathbf{G}_{\mathbf{2}}$. To an ice cooled $70 \mathrm{~mL} \mathrm{CHCl}_{3}$ solution of $3.97 \mathrm{~g}$ of compound $\mathbf{4}-\mathbf{G}_{\mathbf{1}}$ (1.46 mmol, 1.0 eq.) were added $64 \mathrm{~mL}\left(0.24 \mathrm{M}, 15.3 \mathrm{mmol}, 10.5\right.$ eq.) of $\mathrm{H}_{2} \mathrm{NNMeP}(\mathrm{S}) \mathrm{Cl}_{2}$ in $\mathrm{CHCl}_{3}$. The reaction mixture was stirred at room temperature for two hours and checked with NMR for completion. The volume of $\mathrm{CHCl}_{3}$ was reduced and the mixture was precipitated from pentane several times until the excess of $\mathrm{H}_{2} \mathrm{NNMeP}(\mathrm{S}) \mathrm{Cl}_{2}$ was completely removed. Dendrimer $\mathbf{5}-\mathbf{G}_{\mathbf{2}}$ was obtained as a pale yellow solid in 94\% yield (5.97 g, $1.37 \mathrm{mmol}) .{ }^{31} \mathrm{P}\left\{{ }^{1} \mathrm{H}\right\}$-NMR $\left(121.5 \mathrm{MHz}, \mathrm{CDCl}_{3}, \delta\right): 8.3\left(\mathrm{~s}, \mathrm{~N}_{3} \mathrm{P}_{3}\right), 61.9\left(\mathrm{~s}, \mathrm{P}_{1}\right), 62.8\left(\mathrm{~s}, \mathrm{P}_{2}\right)$. ${ }^{1} \mathrm{H}-\mathrm{NMR}\left(300 \mathrm{MHz}, \mathrm{CDCl}_{3}, \delta\right): 1.35\left(\mathrm{~m}, 2 \mathrm{H}, \mathrm{C}^{(3)} \mathrm{H}_{2}\right), 1.61(\mathrm{~m}, 4 \mathrm{H}$, $\mathrm{C}^{(4)} \mathrm{H}_{2}, \mathrm{C}^{(2)} \mathrm{H}_{2}$ ), 1.88 (m, 1H, C ${ }^{(6)} \mathrm{H}_{2}$ ), 2.03 (m, 2H, $\mathrm{C}^{(1)} \mathrm{H}_{2} \mathrm{CO}$ ), $2.42\left(\mathrm{~m}, 1 \mathrm{H}, \mathrm{C}^{(6)} \mathrm{H}_{2}\right), 2.72\left(\mathrm{t}, 2 \mathrm{H}, \mathrm{CH}_{2} \mathrm{Ar}\right), 3.13\left(\mathrm{~m}, 2 \mathrm{H}, \mathrm{C}^{(7)} \mathrm{H}_{2} \mathrm{~S}\right)$, 3.28-3.50 (m, 48H, C $\left.{ }^{(5)} \mathrm{H}-\mathrm{S}, \mathrm{CH}_{2} \mathrm{NH}, \mathrm{P}_{1,2}-\mathrm{N}-\mathrm{CH}_{3}\right), 5.40(\mathrm{~s}, 1 \mathrm{H}$, $\mathrm{NH}), 7.01\left(\mathrm{~m}, 14 \mathrm{H}, \mathrm{C}_{\mathrm{T}}{ }^{2} \mathrm{H}, \mathrm{C}_{0}{ }^{2} \mathrm{H}, \mathrm{C}_{\mathrm{T}}{ }^{3} \mathrm{H}\right), 7.25\left(\mathrm{~m}, 20 \mathrm{H}, \mathrm{C}_{1}{ }^{2} \mathrm{H}\right)$, $7.66\left(\mathrm{~m}, 45 \mathrm{H}, \mathrm{C}_{0}{ }^{3} \mathrm{H}, \mathrm{C}_{1}{ }^{3} \mathrm{H}, \mathrm{CH}=\mathrm{N}-\mathrm{N}\right) .{ }^{13} \mathrm{C}\left\{{ }^{1} \mathrm{H}\right\}-\mathrm{NMR}(75.5 \mathrm{MHz}$, $\left.\mathrm{CDCl}_{3}, \delta\right): 25.3\left(\mathrm{C}^{(2 / 4)} \mathrm{H}_{2}\right), 28.9\left(\mathrm{C}^{(3)} \mathrm{H}_{2}\right), 31.8\left(\mathrm{~d},{ }^{2} J_{\mathrm{CP}}=13.1 \mathrm{~Hz}\right.$, $\left.\mathrm{P}_{2}-\mathrm{N}-\mathrm{CH}_{3}\right), 33.1\left(\mathrm{~d},{ }^{2} J_{\mathrm{CP}}=12.9 \mathrm{~Hz}, \mathrm{P}_{1}-\mathrm{N}-\mathrm{CH}_{3}\right), 34.6\left(\mathrm{C}^{(2 / 4)} \mathrm{H}_{2}\right)$, $35.1\left(\mathrm{CH}_{2} \mathrm{Ar}\right), 36.4\left(\mathrm{C}^{(1)} \mathrm{H}_{2}\right), 38.5\left(\mathrm{C}^{(7)} \mathrm{H}_{2} \mathrm{~S}\right), 40.3\left(\mathrm{C}^{(6)} \mathrm{H}_{2}\right), 40.5$ $\left(\mathrm{CH}_{2} \mathrm{NH}\right), 56.5\left(\mathrm{C}^{(5)} \mathrm{H}-\mathrm{S}\right), 121.0\left(\mathrm{C}_{\mathrm{T}}^{2}\right), 121.4\left(\mathrm{~d},{ }^{3} J_{\mathrm{CP}}=6.2 \mathrm{~Hz}\right.$, $\left.\mathrm{C}_{0}^{2}\right), 121.9\left(\mathrm{~d},{ }^{3} J_{\mathrm{CP}}=4.3 \mathrm{~Hz}, \mathrm{C}_{1}^{2}\right), 128.3\left(\mathrm{C}_{0}{ }^{3}\right), 128.8\left(\mathrm{C}_{1}^{3}\right)$, $129.8\left(\mathrm{C}_{\mathrm{T}}{ }^{3}\right), \quad 131.6\left(\mathrm{C}_{1}{ }^{4}\right), 131.9\left(\mathrm{C}_{0}{ }^{4}\right), 135.9\left(\mathrm{C}_{\mathrm{T}}{ }^{4}\right), 138.9$ $\left(\mathrm{m}, \mathrm{CH}=\mathrm{N}-\mathrm{N}-\mathrm{P}_{1}\right), 140.6\left(\mathrm{~d},{ }^{2} J_{\mathrm{CP}}=18.7 \mathrm{~Hz}, \mathrm{CH}=\mathrm{N}-\mathrm{N}-\mathrm{P}_{2}\right)$, $151.4\left(\mathrm{~m}, \mathrm{C}_{0}{ }^{1}\right), 151.8\left(\mathrm{~d},{ }^{2} J_{\mathrm{CP}}=7.2 \mathrm{~Hz}, \mathrm{C}_{1}{ }^{1}\right), 172.6(\mathrm{NCO})$.

Bifunctional dendrimer $\mathbf{6}-\mathbf{G}_{2}$. In a Schlenk tube, $1.00 \mathrm{~g}$ of compound $\mathbf{5}-\mathbf{G}_{\mathbf{2}}$ (0.231 mmol, 1.0 eq.) was dissolved in $150 \mathrm{~mL}$ of $\mathrm{THF}$ to which $650 \mu \mathrm{L}$ of $N, N$-diethylethylenediamine (4.59 mmol, 19.9 eq.) was added dropwise. The reaction was left to stir overnight at room temperature. The precipitate was washed twice with dry THF, yielding $1.00 \mathrm{~g}(0.15 \mathrm{mmol}, 65 \%)$ of dendrimer 6-G $\mathbf{G}_{2}$ as a pale yellow solid. ${ }^{31} \mathrm{P}\left\{{ }^{1} \mathrm{H}\right\}-\mathrm{NMR}$ (121.5 $\left.\mathrm{MHz} \mathrm{CDCl}_{3}, \delta\right): 8.9\left(\mathrm{~s}, \mathrm{~N}_{3} \mathrm{P}_{3}\right), 62.4\left(\mathrm{~s}, \mathrm{P}_{1}\right), 70.2\left(\mathrm{~s}, \mathrm{P}_{2}\right) \cdot{ }^{1} \mathrm{H}-\mathrm{NMR}$ $\left(300 \mathrm{MHz}, \mathrm{CDCl}_{3}, \delta\right): 1.26\left(\mathrm{t},{ }^{3} J_{\mathrm{HH}}=6.9 \mathrm{~Hz}\right.$, about $15 \mathrm{H}$, $\mathrm{NCH}_{2} \mathrm{CH}_{3}$ ), $1.30\left(\mathrm{t},{ }^{3} \mathrm{~J}_{\mathrm{HH}}=6.9 \mathrm{~Hz}\right.$, about $105 \mathrm{H}, \mathrm{N}^{+} \mathrm{CH}_{2} \mathrm{CH}_{3}$ ), $1.40\left(\mathrm{~m}, 2 \mathrm{H}, \mathrm{C}^{(3)} \mathrm{H}_{2}\right), 1.51\left(\mathrm{~m}, 4 \mathrm{H}, \mathrm{C}^{(4)} \mathrm{H}_{2}, \mathrm{C}^{(2)} \mathrm{H}_{2}\right), 1.85(\mathrm{~m}, 1 \mathrm{H}$, $\left.\mathrm{C}^{(6)} \mathrm{H}_{2}\right), 2.10\left(\mathrm{~m}, 2 \mathrm{H}, \mathrm{C}^{(1)} \mathrm{H}_{2} \mathrm{CO}\right), 2.36\left(\mathrm{~m}, 1 \mathrm{H}, \mathrm{C}^{(6)} \mathrm{H}_{2}\right), 2.79$ (q, ${ }^{3} \mathrm{JHH}_{\mathrm{HH}}=6.9 \mathrm{~Hz}$, about $\left.10 \mathrm{H}, \mathrm{NCH}_{2} \mathrm{CH}_{3}\right), 2.86\left(\mathrm{~m}, 2 \mathrm{H}, \mathrm{CH}_{2} \mathrm{Ar}\right)$, $3.07\left(2 \mathrm{H}, \mathrm{C}^{(7)} \mathrm{H}_{2} \mathrm{~S}\right.$ ), 3.20-3.40 (m, about $198 \mathrm{H}, \mathrm{C}^{(5)} \mathrm{H}-\mathrm{S}, \mathrm{CH}_{2} \mathrm{~N}$, $\left.\mathrm{N}^{+} \mathrm{CH}_{2} \mathrm{CH}_{3}, \mathrm{P}_{1,2}-\mathrm{N}-\mathrm{CH}_{3}\right), 6.90\left(\mathrm{~m}, 2 \mathrm{H}, \mathrm{C}_{\mathrm{T}}{ }^{2}\right), 7.00\left(\mathrm{~m}, 10 \mathrm{H}, \mathrm{C}_{0}^{2}\right)$, $7.11\left(\mathrm{~m}, 2 \mathrm{H}, \mathrm{C}_{\mathrm{T}}{ }^{3}\right), 7.25\left(\mathrm{~m}, 20 \mathrm{H}, \mathrm{C}_{1}{ }^{2}\right), 7.60-7.95\left(\mathrm{~m}, 45 \mathrm{H}, \mathrm{C}_{0}{ }^{3}\right.$, $\left.\mathrm{C}_{1}{ }^{3}, \mathrm{CH}=\mathrm{N}-\mathrm{N}-\mathrm{P}_{1,2}\right) .{ }^{13} \mathrm{C}\left\{{ }^{1} \mathrm{H}\right\}-\mathrm{NMR}\left(75.5 \mathrm{MHz}, \mathrm{CDCl}_{3}, \delta\right): 7.9$ $\left(\mathrm{N}^{+} \mathrm{CH}_{2} \mathrm{CH}_{3}\right), 9.7\left(\mathrm{NCH}_{2} \mathrm{CH}_{3}\right), 25.1\left(\mathrm{C}^{(2 / 4)} \mathrm{H}_{2}\right), 28.5\left(\mathrm{C}^{(3)} \mathrm{H}_{2}\right), 31.3$ $\left(\mathrm{d},{ }^{2} J_{\mathrm{CP}}=9.4 \mathrm{~Hz}, \mathrm{P}_{2}-\mathrm{N}-\mathrm{CH}_{3}\right), 32.5\left(\mathrm{~d},{ }^{2} J_{\mathrm{CP}}=12.2 \mathrm{~Hz}, \mathrm{P}_{1}-\mathrm{N}-\mathrm{CH}_{3}\right)$, $34.4\left(\mathrm{C}^{(2 / 4)} \mathrm{H}_{2}\right), 35.6\left(\mathrm{CH}_{2} \mathrm{Ar}\right), 36.2\left(\mathrm{CH}_{2}-\mathrm{N}-\mathrm{P}_{2}\right), 36.4\left(\mathrm{C}^{(1)} \mathrm{H}_{2}\right), 38.1$ $\left(\mathrm{C}^{(7)} \mathrm{H}_{2} \mathrm{~S}\right), 40.1\left(\mathrm{C}^{(6)} \mathrm{H}_{2}, \mathrm{CH}_{2} \mathrm{NHCO}\right), 49.5\left(\mathrm{~N}-\mathrm{CH}_{2} \mathrm{CH}_{3}\right), \quad 52.2$ $\left(\mathrm{d},{ }^{3} J_{\mathrm{CP}}=6.9 \mathrm{~Hz}, \mathrm{P}_{1}-\mathrm{N}-\mathrm{CH}_{2} \mathrm{CH}_{2}\right), 56.3\left(\mathrm{C}^{(5)} \mathrm{H}-\mathrm{S}\right), 121.0\left(\mathrm{C}_{0}{ }^{2}\right.$, $\left.\mathrm{C}_{\mathrm{T}}{ }^{2}\right), 121.4\left(\mathrm{C}_{1}{ }^{2}\right), 128.0\left(\mathrm{C}_{1}{ }^{3}\right), 128.3\left(\mathrm{C}_{0}{ }^{3}\right), 130.0\left(\mathrm{C}_{\mathrm{T}}{ }^{3}\right), 132.6\left(\mathrm{C}_{0}{ }^{4}\right)$, $133.3\left(\mathrm{C}_{1}{ }^{4}\right), 137.5\left(\mathrm{~d},{ }^{2} \mathrm{~J}_{\mathrm{CP}}=13.4 \mathrm{~Hz}, \mathrm{CH}=\mathrm{N}-\mathrm{N}-\mathrm{P}_{1,2}\right), 151.0$ $\left(\mathrm{m}, \mathrm{C}_{0}{ }^{1}, \mathrm{C}_{\mathrm{T}}{ }^{1}, \mathrm{C}_{1}{ }^{1}\right), 175.0$ (NCO).

Bifunctional dendrimer $\mathbf{4}-\mathbf{G}_{2}$. In a Schlenk tube, $4.00 \mathrm{~g}$ of 5-G $\mathbf{G}_{2}$ (0.916 mmol, 1.0 eq.), $2.45 \mathrm{~g}$ of $p$-hydroxybenzaldehyde (20.1 mmol, 22 eq.) and $11.92 \mathrm{~g}$ of $\mathrm{Cs}_{2} \mathrm{CO}_{3}$ (36.6 mmol, 40 eq.) were dissolved in $600 \mathrm{~mL}$ of THF. The reaction was left to stir overnight at room temperature. The solution was filtered, its volume was reduced and the dendrimer was precipitated from pentane several times until all the excess of $p$-hydroxybenzaldehyde 
was removed. This quantitatively yielded dendrimer $\mathbf{4}-\mathbf{G}_{\mathbf{2}}$ as a pale yellow solid (5.54 g). ${ }^{31} \mathrm{P}\left\{{ }^{1} \mathrm{H}\right\}$-NMR (121.5 MHz, $\mathrm{CDCl}_{3}, \delta$ ): $8.3\left(\mathrm{~s}, \mathrm{~N}_{3} \mathrm{P}_{3}\right), 60.3\left(\mathrm{~s}, \mathrm{P}_{2}\right), 62.3\left(\mathrm{~s}, \mathrm{P}_{1}\right) .{ }^{1} \mathrm{H}-\mathrm{NMR}\left(300 \mathrm{MHz}, \mathrm{CDCl}_{3}\right.$,

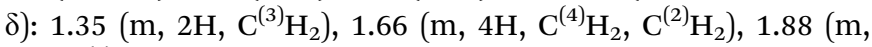
$1 \mathrm{H}, \mathrm{C}^{(6)} \mathrm{H}_{2}$ ), $1.99\left(\mathrm{t},{ }^{3} J_{\mathrm{HH}}=7.2 \mathrm{~Hz}, 2 \mathrm{H}, \mathrm{CH}_{2} \mathrm{CO}\right), 2.34(\mathrm{~m}, 1 \mathrm{H}$, $\left.\mathrm{C}^{(6)} \mathrm{H}_{2}\right), 2.66\left(\mathrm{t},{ }^{3} J_{\mathrm{HH}}=7.2 \mathrm{~Hz}, 2 \mathrm{H}, \mathrm{CH}_{2} \mathrm{Ar}\right), 3.07\left(\mathrm{~m}, 2 \mathrm{H}, \mathrm{C}^{(7)} \mathrm{H}_{2} \mathrm{~S}\right)$, 3.25-3.39 (m, 48H, C $\left.{ }^{(5)} \mathrm{H}-\mathrm{S}, \mathrm{CH}_{2} \mathrm{NH}, \mathrm{P}_{1,2}-\mathrm{N}-\mathrm{CH}_{3}\right), 5.75(\mathrm{~s}, 1 \mathrm{H}$, $\mathrm{NH}), 6.80-7.08\left(\mathrm{~m}, 14 \mathrm{H}, \mathrm{C}_{\mathrm{T}}{ }^{2}, \mathrm{C}_{\mathrm{T}}{ }^{3}, \mathrm{C}_{0}{ }^{2}\right), 7.21\left(\mathrm{~m}, 20 \mathrm{H}, \mathrm{C}_{1}^{2}\right), 7.36$ $\left(\mathrm{m}, 40 \mathrm{H}, \mathrm{C}_{2}{ }^{2}\right), 7.61\left(\mathrm{~m}, 45 \mathrm{H}, \mathrm{C}_{0}{ }^{3}, \mathrm{C}_{1}{ }^{3}, \mathrm{CH}=\mathrm{N}-\mathrm{N}\right), 7.83(\mathrm{~m}, 40 \mathrm{H}$, $\left.\mathrm{C}_{2}{ }^{3}\right), 9.90$ (s, 20H, CHO). ${ }^{13} \mathrm{C}\left\{{ }^{1} \mathrm{H}\right\}-\mathrm{NMR}\left(75.5 \mathrm{MHz}, \mathrm{CDCl}_{3}, \delta\right): 25.3$ $\left(\mathrm{C}^{(2 / 4)} \mathrm{H}_{2}\right), 28.9\left(\mathrm{C}^{(3)} \mathrm{H}_{2}\right), 33.0\left(2 \mathrm{~d},{ }^{2} J_{\mathrm{CP}}=12.8 \mathrm{~Hz}, \mathrm{P}_{1,2}-\mathrm{N}-\mathrm{CH}_{3}\right), 34.5$ $\left(\mathrm{C}^{(2 / 4)} \mathrm{H}_{2}\right), 35.0\left(\mathrm{CH}_{2} \mathrm{Ar}\right), 36.3\left(\mathrm{C}^{(1)} \mathrm{H}_{2}\right), 38.5\left(\mathrm{C}^{(7)} \mathrm{H}_{2} \mathrm{~S}\right), 40.3\left(\mathrm{C}^{(6)} \mathrm{H}_{2}\right.$, $\left.\mathrm{CH}_{2} \mathrm{NH}\right), 56.5\left(\mathrm{C}^{(5)} \mathrm{H}-\mathrm{S}\right), 120.7\left(\mathrm{C}_{\mathrm{T}}^{2}\right), 121.3\left(\mathrm{C}_{0}^{2}\right), 121.3\left(\mathrm{~d},{ }^{3} J_{\mathrm{CP}}=\right.$ $\left.4.0 \mathrm{~Hz}, \mathrm{C}_{1}{ }^{2}\right), 122.0\left(\mathrm{~d},{ }^{3} J_{\mathrm{CP}}=4.8 \mathrm{~Hz}, \mathrm{C}_{2}{ }^{2}\right), 128.4\left(\mathrm{C}_{0,1}{ }^{3}\right), 129.6\left(\mathrm{C}_{\mathrm{T}}{ }^{3}\right)$, $131.5\left(\mathrm{C}_{2}{ }^{3}\right), 132.0\left(\mathrm{C}_{0,1}{ }^{4}\right), 133.7\left(\mathrm{C}_{2}{ }^{4}\right), 135.9\left(\mathrm{C}_{\mathrm{T}}{ }^{4}\right), 139.6\left(2 \mathrm{~d},{ }^{2} J_{\mathrm{CP}}=\right.$ $\left.15.1 \mathrm{~Hz}, \mathrm{CH}=\mathrm{N}-\mathrm{N}-\mathrm{P}_{1,2}\right), 151.5\left(2 \mathrm{~d},{ }^{2} J_{\mathrm{CP}}=7.1 \mathrm{~Hz}, \mathrm{C}_{0,1}{ }^{1}\right), 155.1$ $\left(\mathrm{d},{ }^{2} J_{\mathrm{CP}}=7.2 \mathrm{~Hz}, \mathrm{C}_{2}{ }^{1}\right.$ ), 172.8 (NCO), 190.7 (CHO).

Bifunctional dendrimer $7-\mathbf{G}_{2}$. A mixture of $1.00 \mathrm{~g}$ of compound $4-\mathbf{G}_{2}$ (0.165 mmol, $\left.1.0 \mathrm{eq}.\right), 0.86 \mathrm{~g}$ of malonic acid (8.27 mmol, 50 eq.) and $24.5 \mu \mathrm{L}$ of piperidine (freshly distilled over $\mathrm{CaH}_{2}$ ) was stirred in $15 \mathrm{~mL}$ of pyridine at $95{ }^{\circ} \mathrm{C}$ overnight. After 15 minutes of reflux to remove the $\mathrm{CO}_{2}$, the mixture was left to cool down and precipitated on ice-cold $\mathrm{HCl}(37 \%)$. The precipitate was washed 3 times with water and twice with ether before it was dried under reduced pressure. After dissolution in water and subsequent ion exchange with $12 \mathrm{~mL}$ of $0.1996 \mathrm{M}$ $\mathrm{NaOH}$ (aq) (14.5 eq.) the solution was freeze-dried. $0.858 \mathrm{~g}$ of dendrimer $7-\mathbf{G}_{\mathbf{2}}(0.117 \mathrm{mmol}, 71 \%)$ was obtained as a pale yellow solid. The NMR spectra were recorded before ion exchange (COOH terminated dendrimers). ${ }^{31} \mathrm{P}\left\{{ }^{1} \mathrm{H}\right\}$-NMR $(121.5 \mathrm{MHz}$, DMSO- $\left.d_{6}, \delta\right): 8.4\left(\mathrm{~s}, \mathrm{~N}_{3} \mathrm{P}_{3}\right), 62.0\left(\mathrm{~s}, \mathrm{P}_{2}\right), 62.4\left(\mathrm{~s}, \mathrm{P}_{1}\right) .{ }^{1} \mathrm{H}-\mathrm{NMR}$ (300 MHz, DMSO- $\left.d_{6}, \delta\right): 1.23\left(\mathrm{~m}, 2 \mathrm{H}, \mathrm{C}^{(3)} \mathrm{H}_{2}\right), 1.36\left(\mathrm{~m}, 4 \mathrm{H}, \mathrm{C}^{(4)} \mathrm{H}_{2}\right.$, $\left.\mathrm{C}^{(2)} \mathrm{H}_{2}\right), 1.75\left(\mathrm{~m}, 1 \mathrm{H}, \mathrm{C}^{(6)} \mathrm{H}_{2}\right), 1.90\left(\mathrm{~m}, 2 \mathrm{H}, \mathrm{CH}_{2} \mathrm{CO}\right), 2.18(\mathrm{~m}, 1 \mathrm{H}$, $\mathrm{C}^{(6)} \mathrm{H}_{2}$ ), 2.57 (m, 2H, $\left.\mathrm{CH}_{2} \mathrm{Ar}\right), 2.99\left(\mathrm{~m}, 2 \mathrm{H}, \mathrm{C}^{(7)} \mathrm{H}_{2} \mathrm{~S}\right), 3.12-3.59$ $\left(\mathrm{m}, 48 \mathrm{H}, \mathrm{C}^{(5)} \mathrm{H}-\mathrm{S}, \mathrm{CH}_{2} \mathrm{NH}, \mathrm{P}_{1,2}-\mathrm{N}-\mathrm{CH}_{3}\right), 6.43\left(\mathrm{~d},{ }^{3} \mathrm{~J}_{\mathrm{HH}}=16.2 \mathrm{~Hz}\right.$, $\left.20 \mathrm{H}, \mathrm{CH}=\mathrm{CHCO}_{2}\right), 6.85\left(\mathrm{~m}, 2 \mathrm{H}, \mathrm{C}_{\mathrm{T}}{ }^{2} \mathrm{H}\right), 6.98\left(\mathrm{~m}, 12 \mathrm{H}, \mathrm{C}_{\mathrm{T}}{ }^{3} \mathrm{H}\right.$, $\left.\mathrm{C}_{0}{ }^{2} \mathrm{H}\right), 7.18\left(\mathrm{~m}, 60 \mathrm{H}, \mathrm{C}_{1}{ }^{2} \mathrm{H}, \mathrm{C}_{2}{ }^{2} \mathrm{H}\right), 7.53\left(\mathrm{~d},{ }^{3} J_{\mathrm{HH}}=16.2 \mathrm{~Hz}, 20 \mathrm{H}\right.$, $\left.\mathrm{CH}=\mathrm{CHCO}_{2}\right), 7.66\left(\mathrm{~m}, 70 \mathrm{H}, \mathrm{C}_{0}{ }^{3} \mathrm{H}, \mathrm{C}_{1}{ }^{3} \mathrm{H}, \mathrm{C}_{2}{ }^{3} \mathrm{H}\right), 7.88(\mathrm{~m}, 15 \mathrm{H}$, $\mathrm{CH}=\mathrm{N}-\mathrm{N}), \quad 12.4(\mathrm{COOH}, 20 \mathrm{H}) .{ }^{13} \mathrm{C}\left\{{ }^{1} \mathrm{H}\right\}-\mathrm{NMR} \quad(75.5 \mathrm{MHz}$, DMSO- $\left.d_{6}, \delta\right): 25.4\left(\mathrm{C}^{(2 / 4)} \mathrm{H}_{2}\right), 28.7\left(\mathrm{C}^{(3)} \mathrm{H}_{2}\right), 33.4\left(\mathrm{~m}, \mathrm{P}_{1,2}-\mathrm{N}-\mathrm{CH}_{3}\right)$, $34.0\left(\mathrm{C}^{(2 / 4)} \mathrm{H}_{2}\right), 34.5\left(\mathrm{CH}_{2} \mathrm{Ar}\right), 35.6\left(\mathrm{C}^{(1)} \mathrm{H}_{2}\right), 38.4\left(\mathrm{C}^{(7)} \mathrm{H}_{2} \mathrm{~S}\right), 56.5$ $\left(\mathrm{C}^{(5)} \mathrm{H}-\mathrm{S}\right), 119.8(\mathrm{Ar}-\mathrm{CH}=\mathrm{CH}), 120.6\left(\mathrm{C}_{0}^{2}, \mathrm{C}_{\mathrm{T}}{ }^{2}\right), 121.8\left(\mathrm{~d},{ }^{3} J_{\mathrm{CP}}=\right.$ $\left.4.8 \mathrm{~Hz}, \mathrm{C}_{1}{ }^{2}, \mathrm{C}_{2}{ }^{2}\right), 128.8\left(\mathrm{C}_{\mathrm{T}, 0,1}{ }^{3}\right), 130.3\left(\mathrm{C}_{2}{ }^{3}\right), 132.2\left(\mathrm{C}_{2}{ }^{4}\right), 132.5$ $\left(\mathrm{C}_{0,1}{ }^{4}\right), 141.1\left(\mathrm{~m}, \mathrm{CH}=\mathrm{N}-\mathrm{N}-\mathrm{P}_{1,2}\right), 143.1(\mathrm{Ar}-\mathrm{CH}=\mathrm{CH}), 151.3$ $\left(\mathrm{d},{ }^{5} J_{\mathrm{CP}}=6.9 \mathrm{~Hz}, \mathrm{C}_{0,1}{ }^{1}\right), 151.7\left(\mathrm{~d},{ }^{5} J_{\mathrm{CP}}=6.9 \mathrm{~Hz}, \mathrm{C}_{2}{ }^{1}\right), 167.9$ (COOH), 172.4 (NCO). ( $\mathrm{C}^{(6)} \mathrm{H}_{2}$ and $\mathrm{CH}_{2} \mathrm{NH}$ hidden by DMSO).

\section{Surface plasmon resonance spectroscopy}

Dendrimers were adsorbed on template stripped gold, which was prepared following the described procedure. ${ }^{51}$ The freshly prepared gold samples were mounted onto a customized surface plasmon resonance ${ }^{52}$ spectrometer and a $1 \mathrm{mg} \mathrm{mL}^{-1}$ aqueous solution of either $\mathbf{6}-\mathbf{G}_{\mathbf{1}}$ or $\mathbf{7}-\mathbf{G}_{\mathbf{1}}$ was added. The formation of the dendrimer layers was followed in real time as an increase in SPR reflectivity, which could be translated into a layer thickness. The laser used was a HeNe laser with one spectral line at $632.8 \mathrm{~nm}$.

\section{Contact angle goniometry}

The hydrophobicity of the different coatings was measured with an OCA 15+ (DataPhysics, Filderstadt, Germany) goniometer equipped with a CCD camera and an electronic dosing unit. For the determination of the contact angles, SCA 20 software was used. The droplet volume was $3 \mu \mathrm{L}$ and the water was degassed before usage. Measurements were performed in 5-fold.

\section{Cell experiments}

A cell bank of a commercial cell line was created (HOB, human hipbone osteoblasts, promocell, Heidelberg, Germany). HOB cells were cultured at $37{ }^{\circ} \mathrm{C}$ and $5 \% \mathrm{CO}_{2}$ in commercially available $\mathrm{HOB}$ Growth medium, containing a promocell supplement mix. The proliferation of the cells was followed by optical inspection. The coated glass substrates were sterilized and transferred to a petri-dish containing $3 \mathrm{~mL}$ of growth medium and $2.0 \times 10^{4} \mathrm{HOB}$ cells per $\mathrm{mL}$. The growth medium was changed every $48 \mathrm{~h}$.

After about 300 hours, $80-100 \%$ confluence was reached and cells were trypsinated and counted. $20 \mu \mathrm{L}$ of the solution left after trypsination were mixed with an equal amount of Trypan Blue stain (GIBCO, 0.4\%). The cell suspension was transferred to a Neubauer cell counter. Subsequently, the relative number of living cells (stained brightly blue) with respect to the total number of cells (including dead cells, stained dark blue) was determined.

After trypsination, the cells were transferred from the sample surface to a 96-well Elisa plate. The cells were allowed to re-attach to the Elisa walls for approximately 24 hours in HOB growth medium. $100 \mu \mathrm{L}$ medium was left in each Elisa well and mixed with $100 \mu \mathrm{L}$ of the assay solution (Caspase-Glo ${ }^{\circledR} 3 / 7$, Promega). Subsequently, the Elisa plate was kept in the dark for 30 minutes for the assay to reach full activity and then measured with a Promega luminometer.

$50 \mu \mathrm{L}$ of an aqueous DAPI solution (4',6-diamidino-2-phenylindole dihydrochloride. $2 \mathrm{mg} \mathrm{mL}{ }^{-1}$, Carl Roth $\mathrm{GmbH}$, Karlsruhe, Germany) were added to the cell culture. Cells were imaged using an Olympus IX 70 microscope (Olympus, Center Valley, USA). Images were recorded at 400-fold magnification using a CCD camera.

\section{Acknowledgements}

The European framework program 6 (Marie-Curie EST NANOTOOL) and the Max Planck Society are gratefully acknowledged for funding (ERJ). Thanks are due also to the CNRS (Centre National de la Recherche Scientifique) for financial support, and the COST action CM1302 SIPs.

\section{Notes and references}

1 Dendrimers. Towards Catalytic, Material and Biomedical Uses, ed. A. M. Caminade, C. O. Turrin, R. Laurent, A. Ouali and B. Delavaux-Nicot, John Wiley \& Sons, Chichester, UK, 2011. 
2 O. Rolland, C. O. Turrin, A. M. Caminade and J. P. Majoral, New J. Chem., 2009, 33, 1809.

3 L. Roglin, E. H. M. Lempens and E. W. Meijer, Angew. Chem., Int. Ed., 2011, 50, 102; P. Antoni, Y. Hed, A. Nordberg, D. Nystrom, H. von Holst, A. Hult and M. Malkoch, Angew. Chem., Int. Ed., 2009, 48, 2126; R. Al-Hellani, J. Barner, J. P. Rabe and A. D. Schluter, Chem. - Eur. J., 2006, 12, 6542; H. Zong, T. P. Thomas, K. H. Lee, A. M. Desai, M. H. Li, A. Kotlyar, Y. H. Zhang, P. R. Leroueil, J. J. Gam, M. M. B. Holl and J. R. Baker, Biomacromolecules, 2012, 13, 982.

4 K. Kanie, M. Matsubara, X. B. Zeng, F. Liu, G. Ungar, H. Nakamura and A. Muramatsu, J. Am. Chem. Soc., 2012, 134, 808; G. Lamanna, M. Kueny-Stotz, H. MamloukChaouachi, C. Ghobril, B. Basly, A. Bertin, I. Miladi, C. Billotey, G. Pourroy, S. Begin-Colin and D. Felder-Flesch, Biomaterials, 2011, 32, 8562.

5 T. A. Horbett, J. J. Waldburger, B. D. Ratner and A. S. Hoffman, J. Biomed. Mater. Res., 1988, 22, 383.

6 B. Hopp, N. Kresz, J. Kokavecz, T. Smausz, H. Schieferdecker, A. Doring, O. Marti and Z. Bor, Appl. Surf. Sci., 2004, 221, 437.

7 A. Dekker, T. Beugeling, H. Wind, A. Poot, A. Bantjes, J. Feijen and W. G. Van Aken, J. Mater. Sci.: Mater. Med., 1991, 2, 227.

8 V. I. Sikavitsas, J. S. Temenoff and A. G. Mikos, Biomaterials, 2001, 22, 2581.

9 K. Kato, S. Sano and Y. Ikada, Colloids Surf., B, 1995, 4, 221; J. S. Mao, Y. L. Cui, X. H. Wang, Y. Sun, Y. J. Yin, H. M. Zhao and K. De Yao, Biomaterials, 2004, 25, 3973; G. Rainaldi, P. Filippini, A. Ferrante, P. L. Indovina and M. T. Santini, J. Biomed. Mater. Res., 2001, 55, 104; M. Wahlgren and T. Arnebrant, Trends Biotechnol., 1991, 9, 201.

10 C. R. Wittmer, J. A. Phelps, W. M. Saltzman and P. R. Van Tassel, Biomaterials, 2007, 28, 851.

11 See for instance: R. K. Aithal, D. P. Kumaraswamy, D. K. Milis and D. Kuila, J. Biomed. Nanotechnol., 2007, 3, 254; A. P. Zhu and N. Fang, Biomacromolecules, 2005, 6, 2607.

12 S. F. Rose, A. L. Lewis, G. W. Hanlon and A. W. Lloyd, Biomaterials, 2004, 25, 5125.

13 J. L. Hernandez-Lopez, H. L. Khor, A. M. Caminade, J. P. Majoral, S. Mittler, W. Knoll and D. H. Kim, Thin Solid Films, 2008, 516, 1256.

14 S. R. Benhabbour, H. Sheardown and A. Adronov, Biomaterials, 2008, 29, 4177.

15 M. H. Kim, M. Kino-oka and M. Taya, Biotechnol. Adv., 2010, 28, 7 .

16 S. Mashayekhan, M. H. Kim, M. Kino-oka, J. Miyazaki and M. Taya, Polymers, 2011, 3, 2078.

17 J. H. Myung, K. A. Gajjar, J. Saric, D. T. Eddington and S. Hong, Angew. Chem., Int. Ed., 2011, 50, 11769.

18 B. Finke, F. Luethen, K. Schroeder, P. D. Mueller, C. Bergemann, M. Frant, A. Ohl and B. J. Nebe, Biomaterials, 2007, 28, 4521; Y. Cai, M. Frant, J. Bossert, G. Hildebrand, K. Liefeith and K. D. Jandt, Colloids Surf., B, 2006, 50, 1.

19 B. Nebe, B. Finke, F. Luthen, C. Bergemann, K. Schroder, J. Rychly, K. Liefeith and A. Ohl, Biomol. Eng., 2007, 24, 447.
20 M. Lehnert, M. Gorbahn, C. Rosin, M. Klein, I. Köper, B. AlNawas, W. Knoll and M. Veith, Langmuir, 2011, 27, 7743.

21 A. M. Caminade, C. O. Turrin and J. P. Majoral, New J. Chem., 2010, 34, 1512.

22 D. H. Kim, P. Karan, P. Goring, J. Leclaire, A. M. Caminade, J. P. Majoral, U. Gosele, M. Steinhart and W. Knoll, Small, 2005, 1, 99; T. D. Lazzara, K. H. A. Lau, A. I. Abou-Kandil, A. M. Caminade, J. P. Majoral and W. Knoll, ACS Nano, 2010, 4, 3909.

23 A. M. Caminade and J. P. Majoral, Prog. Polym. Sci., 2005, 30, 491.

24 O. Rolland, L. Griffe, M. Poupot, A. Maraval, A. Ouali, Y. Coppel, J. J. Fournié, G. Bacquet, C. O. Turrin, A. M. Caminade, J. P. Majoral and R. Poupot, Chem. - Eur. J., 2008, 14, 4836; D. Riegert, A. Pla-Quintana, S. Fuchs, R. Laurent, C. O. Turrin, C. Duhayon, J. P. Majoral, A. Chaumonnot and A. M. Caminade, Eur. J. Org. Chem., 2013, 5414.

25 V. Maraval, A. M. Caminade, J. P. Majoral and J. C. Blais, Angew. Chem., Int. Ed., 2003, 42, 1822.

26 M. Slany, A. M Caminade and J. P. Majoral, Tetrahedron Lett., 1996, 37, 9053.

27 N. Launay, A. M. Caminade, R. Lahana and J. P. Majoral, Angew. Chem., Int. Ed. Engl., 1994, 33, 1589.

28 G. Franc, S. Mazeres, C. O. Turrin, L. Vendier, C. Duhayon, A. M. Caminade and J. P. Majoral, J. Org. Chem., 2007, 72, 8707.

29 C. Loup, M. A. Zanta, A. M. Caminade, J. P. Majoral and B. Meunier, Chem. - Eur. J., 1999, 5, 3644.

30 G. Soler-Illia, L. Rozes, M. K. Boggiano, C. Sanchez, C. O. Turrin, A. M. Caminade and J. P. Majoral, Angew. Chem., Int. Ed., 2000, 39, 4250.

31 E. Oh, J. B. Delehanty, K. E. Sapsford, K. Susumu, R. Goswami, J. B. Blanco-Canosa, P. E. Dawson, J. Granek, M. Shoff, Q. Zhang, P. L. Goering, A. Huston and I. L. Medintz, ACS Nano, 2011, 5, 6434.

32 J. Voros, Biophys. J., 2004, 87, 553.

33 J. Leclaire, Y. Coppel, A. M. Caminade and J. P. Majoral, J. Am. Chem. Soc., 2004, 126, 2304.

34 M. Bovellan, M. Fritzsche, C. Stevens and G. Charras, FEBS J., 2010, 277, 58.

35 D. Fischer, Y. X. Li, B. Ahlemeyer, J. Krieglstein and T. Kissel, Biomaterials, 2003, 24, 1121.

36 N. A. Stasko, C. B. Johnson, M. H. Schoenfisch, T. A. Johnson and E. L. Holmuhamedov, Biomacromolecules, 2007, 8, 3853.

37 P. Ferruti, S. Knobloch, E. Ranucci, R. Duncan and E. Gianasi, Macromol. Chem. Phys., 1998, 199, 2565.

38 C. Gretzer, M. Werthen and P. Thomsen, Biomaterials, 2002, 23, 1639; A. Terada, A. Yuasa, T. Kushimoto, S. Tsuneda, A. Katakai and M. Tamada, Microbiology, 2006, 152, 3575.

39 C. Galli, M. Piemontese, S. T. Meikle, M. Santin, G. M. Macaluso and G. Passeri, Clin. Oral Implants Res., 2014, 25, E133; C. Zhao, C. Pan, J. Sandstedt, Y. Fu, A. Lindahl and J. Liu, RSC Adv., 2015, $5,42276$.

40 S. P. Hong, A. U. Bielinska, A. Mecke, B. Keszler, J. L. Beals, X. Y. Shi, L. Balogh, B. G. Orr, J. R. Baker and M. M. B. Holl, Bioconjugate Chem., 2004, 15, 774; X. Y. Shi, S. H. Wang, 
H. P. Sun and J. R. Baker, Soft Matter, 2007, 3, 71-74; X. Y. Shi, I. Lee, X. S. Chen, M. W. Shen, S. L. Xiao, M. F. Zhu, J. R. Baker and S. H. Wang, Soft Matter, 2010, 6, 2539.

41 V. Briz, M. J. Serramia, R. Madrid, A. Hameau, A. M. Caminade, J. P. Majoral and M. A. Munoz-Fernandez, Curr. Med. Chem., 2012, 19, 5044.

42 J. Solassol, C. Crozet, V. Perrier, J. Leclaire, F. Beranger, A. M. Caminade, B. Meunier, D. Dormont, J. P. Majoral and S. Lehmann, J. Gen. Virol., 2004, 85, 1791.

43 T. Wasiak, M. Ionov, K. Nieznanski, H. Nieznanska, O. Klementieva, M. Granell, J. Cladera, J. P. Majoral, A. M. Caminade and B. Klajnert, Mol. Pharm., 2012, 9, 458; T. Wasiak, M. Marcinkowska, I. Pieszynski, M. Zablocka, A. M. Caminade, J. P. Majoral and B. Klajnert-Maculewicz, New J. Chem., 2015, 39, 4852.

44 P. Gomulak, B. Klajnert, M. Bryszewska, J. P. Majoral, A. M. Caminade and J. Blasiak, Curr. Med. Chem., 2012, 19, 6233.

45 L. Griffe, M. Poupot, P. Marchand, A. Maraval, C. O. Turrin, O. Rolland, P. Metivier, G. Bacquet, J. J. Fournie, A. M. Caminade, R. Poupot and J. P. Majoral, Angew. Chem., Int. Ed., 2007, 46, 2523; A. M. Caminade, S. Fruchon, C. O. Turrin, M. Poupot, A. Ouali, A. Maraval, M. Garzoni, M. Maly, V. Furer, V. Kovalenko, J. P. Majoral, G. M. Pavan and R. Poupot, Nat. Commun., DOI: 10.1038/ncomms8722.
46 M. Hayder, M. Poupot, M. Baron, D. Nigon, C. O. Turrin, A. M. Caminade, J. P. Majoral, R. A. Eisenberg, J. J. Fournie, A. Cantagrel, R. Poupot and J. L. Davignon, Sci. Transl. Med., 2011, 3, 81ra35; S. Fruchon, S. Mouriot, T. Thiollier, C. Grandin, A. M. Caminade, C. O. Turrin, H. Contamin and R. Poupot, Nanotoxicology, 2015, 9, 433.

47 M. Blanzat, C. O. Turrin, A. M. Aubertin, C. Couturier-Vidal, A. M. Caminade, J. P. Majoral, I. Rico-Lattes and A. Lattes, ChemBioChem, 2005, 6, 2207.

48 G. Spataro, F. Malecaze, C. O. Turrin, V. Soler, C. Duhayon, P. P. Elena, J. P. Majoral and A. M. Caminade, Eur. J. Med. Chem., 2010, 45, 326.

49 L. A. Dykman and N. G. Khlebtsov, Chem. Rev., 2014, 114, 1258; D. A. Giljohann, D. S. Seferos, W. L. Daniel, M. D. Massich, P. C. Patel and C. A. Mirkin, Angew. Chem., Int. Ed., 2010, 49, 3280; C. J. Murphy, A. M. Gole, J. W. Stone, P. N. Sisco, A. M. Alkilany, E. C. Goldsmith and S. C. Baxter, Acc. Chem. Res., 2008, 41, 1721-1730; R. A. Sperling, P. Rivera Gil, F. Zhang, M. Zanella and W. J. Parak, Chem. Soc. Rev., 2008, 37, 1896.

50 M. L. Lartigue, N. Launay, B. Donnadieu, A. M. Caminade and J. P. Majoral, Bull. Soc. Chim. Fr., 1997, 134, 981.

51 R. Naumann, S. M. Schiller, F. Giess, B. Grohe, K. B. Hartman, I. Karcher, I. Koper, J. Lubben, K. Vasilev and W. Knoll, Langmuir, 2003, 19, 5435.

52 W. Knoll, Annu. Rev. Phys. Chem., 1998, 49, 569. 